medRxiv preprint doi: https://doi.org/10.1101/2020.11.16.20232561; this version posted February 2, 2021. The copyright holder for this preprint (which was not certified by peer review) is the author/funder, who has granted medRxiv a license to display the preprint in It is made available under a CC-BY-NC-ND 4.0 International license.

Running head: LOWER LOCUS COERULEUS INTEGRITY IN ALZHEIMER'S

\title{
Locus coeruleus integrity is related to tau burden and memory loss in autosomal-dominant Alzheimer's disease
}

\section{Authors:}

Martin J. Dahl*1,2, Mara Mather ${ }^{2}$, Markus Werkle-Bergner ${ }^{1}$, Briana L. Kennedy ${ }^{2,3}$, Samuel Guzman ${ }^{4}$, Kyle Hurth $^{4}$, Carol A. Miller ${ }^{4}$, Yuchuan Qiao ${ }^{5}$, Yonggang Shi ${ }^{5}$, Helena C. Chui ${ }^{6}, \&$ John M. Ringman $^{6}$

\section{Affiliations:}

${ }^{1}$ Center for Lifespan Psychology, Max Planck Institute for Human Development, 14195 Berlin, Germany

${ }^{2}$ Davis School of Gerontology, University of Southern California, 90089 Los Angeles, CA, USA

${ }^{3}$ School of Psychological Science, University of Western Australia, Perth, Australia

${ }^{4}$ Department of Pathology, Keck School of Medicine, University of Southern California, Los Angeles, CA, USA ${ }^{5}$ Laboratory of Neuro Imaging (LONI), USC Stevens Neuroimaging and Informatics Institute, Keck School of Medicine, University of Southern California, Los Angeles, CA, USA

${ }^{6}$ Department of Neurology, Keck School of Medicine, University of Southern California, 90033 Los Angeles, CA, USA

\section{* Corresponding author:}

MJD (dahl@mpib-berlin.mpg.de) 
medRxiv preprint doi: https://doi.org/10.1101/2020.11.16.20232561; this version posted February 2, 2021. The copyright holder for this preprint (which was not certified by peer review) is the author/funder, who has granted medRxiv a license to display the preprint in It is made available under a CC-BY-NC-ND 4.0 International license

\section{Abstract}

Abnormally phosphorylated tau, an indicator of Alzheimer's disease, accumulates in the first 3 decades of life in the locus coeruleus (LC), the brain's main norepinephrine supply. However, 4 technical challenges in reliable in-vivo assessments have impeded research into the role of the LC in 5 Alzheimer's disease.

We studied participants with or known to be at-risk for mutations in genes causing autosomal7 dominant Alzheimer's disease (ADAD) of early onset, providing a unique window into the 8 pathogenesis of Alzheimer's largely disentangled from age-related factors. Using high-resolution MRI 9 and tau PET, we revealed lower rostral LC integrity in symptomatic participants. LC integrity was associated with individual differences in tau burden and memory decline. Post-mortem analyses in a separate set of carriers of the same mutation confirmed substantial neuronal loss in the LC.

Our findings link LC degeneration to tau burden and memory in Alzheimer's and highlight a 13 role of the noradrenergic system in this neurodegenerative disease.

14 Keywords: Locus coeruleus; autosomal-dominant Alzheimer's disease; norepinephrine; tau 15 pathology; neurodegeneration; A431E 
medRxiv preprint doi: https://doi.org/10.1101/2020.11.16.20232561; this version posted February $2,2021$. The copyright holder for this preprint (which was not certified by peer review) is the author/funder, who has granted medRxiv a license to display the preprint in It is made available under a CC-BY-NC-ND 4.0 International license .

LOWER LOCUS COERULEUS INTEGRITY IN ALZHEIMER'S

\section{Introduction}

Alzheimer's disease (AD) is presently an incurable neurodegenerative disease leading to dementia with the number of worldwide cases predicted to triple over the next thirty years (Alzheimer's Disease International, 2019; Canter, Penney, \& Tsai, 2016; World Health Organization, 2004). Post-mortem studies indicate that abnormally phosphorylated tau, an indicator of $\mathrm{AD}$, begins to appear early in life in the locus coeruleus (LC), the primary source of cortical norepinephrine (Braak, Thal, Ghebremedhin, \& Del Tredici, 2011; Ehrenberg et al., 2017; Poe et al., 2020; Stratmann et al., 2016; Theofilas, Dunlop, Heinsen, \& Grinberg, 2015). With increasing age, abnormal tau appears in a characteristic topographical sequence in noradrenergic projection targets like the mediotemporal lobe (referred to as Braak stages, a classification system of the progression of tau spread; Braak et al., 2011; Chalermpalanupap, Weinshenker, \& Rorabaugh, 2017; Stratmann et al., 2016). Specifically, using an animal model, Gosh and colleagues demonstrated that injecting hyperphosphorylated human tau into the rodent LC leads to its slow spread to other brainstem nuclei and eventually to cortical regions (Ghosh et al., 2019).

Tau deposition is strongly linked to both neural and cognitive decline in Alzheimer's (Hanseeuw et al., 2019; Jagust, 2018; La Joie et al., 2020). Tau burden in the LC increases linearly with the progression of Braak stages while noradrenergic neurons first decrease in size and then degenerate (Ehrenberg et al., 2017; Kelly et al., 2017; Theofilas et al., 2017). Indeed, a meta-analysis of twenty-four post-mortem investigations revealed substantial cell loss in the LC of Alzheimer's patients relative to controls (mean $\mathrm{d}=2.28 ; 95 \% \mathrm{CI}=2.06-$ 2.51; Lyness, Zarow, \& Chui, 2003), and reduced neuron counts are evident already at prodromal stages of the disease (Arendt, Brückner, Morawski, Jäger, \& Gertz, 2015; Kelly et al., 2017). Topographically, noradrenergic neurodegeneration is most pronounced in rostral and middle segments of the nucleus that project to the hippocampus and other memoryrelevant areas (Ehrenberg et al., 2017; Lyness et al., 2003). LC degeneration, however, does 
medRxiv preprint doi: https://doi.org/10.1101/2020.11.16.20232561; this version posted February 2, 2021. The copyright holder for this preprint (which was not certified by peer review) is the author/funder, who has granted medRxiv a license to display the preprint in It is made available under a CC-BY-NC-ND 4.0 International license.

LOWER LOCUS COERULEUS INTEGRITY IN ALZHEIMER'S

not only constitute a consequence of Alzheimer's pathology but also may contribute to its disease development (Marien, Colpaert, \& Rosenquist, 2004; Mather \& Harley, 2016; Satoh \& Iijima, 2019; Weinshenker, 2018). Studies with genetically modified animals indicate that abnormally phosphorylated tau in the LC leads to dysfunctional noradrenergic neuromodulation in memory-relevant brain areas (Ghosh et al., 2019; Rorabaugh et al., 2017; Weinshenker, 2018) and that tau pathology and LC degeneration synergistically aggravate neural and behavioral deterioration (Chalermpalanupap et al., 2018; also see Jacobs, Riphagen, Ramakers, \& Verhey, 2019). Specifically, experimentally decreased norepinephrine levels have been associated with increased tau and amyloid- $\beta$ deposition, another hallmark of AD (Chalermpalanupap et al., 2018; Heneka et al., 2010). Insights into the role of noradrenergic neurodegeneration in the progression of AD are thus of high clinical significance (Grinberg \& Heinsen, 2017), yet in-vivo human data are scarce.

Studies in humans have been impeded by methodological challenges in non-invasive assessments of the LC due to its small size and its location deep within the brainstem (for discussions, see Astafiev, Snyder, Shulman, \& Corbetta, 2010; Keren, Lozar, Harris, Morgan, \& Eckert, 2009). Advances in high-resolution brainstem magnetic resonance imaging (MRI) may help the field overcome these hurdles (Betts, Kirilina, et al., 2019; Liu et al., 2017; Sun et al., 2020). Over the last fifteen years, several MRI sequences have been developed that reveal the LC as a hyperintense cluster of voxels bordering the fourth ventricle (e.g., Betts, Cardenas-Blanco, Kanowski, Jessen, \& Düzel, 2017; Nakane, Nihashi, Kawai, \& Naganawa, 2008; Priovoulos et al., 2017; Sasaki et al., 2006). Keren and colleagues (2015) validated a MR-based LC imaging sequence by first scanning human post-mortem samples at ultra-high field strength and afterwards performing histological analyses of the same samples. They demonstrated that the hyperintensities observed on MRI scans closely co-localize with noradrenergic cells as identified by tyrosine hydroxylase (the rate-limiting enzyme of catecholamine synthesis) staining, opening the door for non-invasive LC assessments (Keren 
medRxiv preprint doi: https://doi.org/10.1101/2020.11.16.20232561; this version posted February 2, 2021. The copyright holder for this preprint (which was not certified by peer review) is the author/funder, who has granted medRxiv a license to display the preprint in It is made available under a CC-BY-NC-ND 4.0 International license .

LOWER LOCUS COERULEUS INTEGRITY IN ALZHEIMER'S

et al., 2015; also see Cassidy et al., 2019 for a postmortem validation in dopaminergic structures and Betts, Kirilina, et al., 2019 for a discussion of potential contrast mechanisms). Probing the utility of LC MRI to detect pathology-related changes in the noradrenergic system in vivo, several studies compared patients diagnosed with AD to healthy controls (Betts, Cardenas-Blanco, et al., 2019; Dordevic et al., 2017; Miyoshi et al., 2013; Takahashi et al., 2015). In general agreement with earlier post-mortem investigations (Lyness et al., 2003), the majority of studies observed lower LC MR-intensity, a proxy for the density of noradrenergic cells (Keren et al., 2015), in the patient groups (but see Miyoshi et al., 2013). However, all of these studies investigated the by far most common, late-onset type of AD (>65 years; LOAD). LOAD is considered a heterogeneous, age-related disease that encompasses not only tau and amyloid pathology but also the aggregation of other proteins such as $\alpha$-synuclein, the effects of cerebrovascular ischemia, and other processes (Jagust, 2018; Van Cauwenberghe, Van Broeckhoven, \& Sleegers, 2016). Given that large lifespan studies suggest spatially confined age differences in LC integrity in healthy older adults (Dahl et al., 2019; Liu et al., 2019), unambiguously distinguishing disease- from age-related changes on this basis is challenging (Lindenberger, von Oertzen, Ghisletta, \& Hertzog, 2011). Focusing instead on forms of $\mathrm{AD}$ that begin early in life allows the possibility of distinguishing age- from disease-related changes (cf. Jacobs, Becker, et al., 2019). Autosomal dominant Alzheimer's (ADAD) is a rare inherited disease caused by mutations in genes associated with the generation or accumulation of amyloid- $\beta$ (Bertram, Lill, \& Tanzi, 2010; Tanzi \& Bertram, 2005; Van Cauwenberghe et al., 2016). In contrast to LOAD, it constitutes a relatively "pure" tau and amyloid pathology in which cerebrovascularor other age-related neuropathological changes are absent (Jagust, 2018; Ringman et al., 2016). In ADAD, symptoms develop early in life with a relatively predictable age at onset (Ryman et al., 2014), thus providing a unique window into the pathogenesis of Alzheimer's (Bateman et al., 2012; Ringman, 2005). Whether or not there is MR-identifiable LC 
medRxiv preprint doi: https://doi.org/10.1101/2020.11.16.20232561; this version posted February 2, 2021. The copyright holder for this preprint (which was not certified by peer review) is the author/funder, who has granted medRxiv a license to display the preprint in It is made available under a CC-BY-NC-ND 4.0 International license . LOWER LOCUS COERULEUS INTEGRITY IN ALZHEIMER'S

degeneration also in patients diagnosed with Alzheimer's dementia early in life is still an open question. Importantly, answering this question could help shed light on whether LC involvement is a core feature of $\mathrm{AD}$ or whether it should be considered more indicative of a non-Alzheimer's process generally associated with aging, such as the process outlined in the “primary age-related tauopathy" framework (Crary et al., 2014).

While previous post-mortem research suggests a topographical pattern of noradrenergic neurodegeneration within the LC in LOAD (Ehrenberg et al., 2017; Lyness et al., 2003), most current in-vivo (MRI) studies lack the spatial specificity to draw comparable conclusions. That is, they report disease-related differences in MR-indexed LC integrity (Dordevic et al., 2017; Takahashi et al., 2015) without exploring potential topographical patterns therein, precluding direct comparisons (but see Betts, Cardenas-Blanco, et al., 2019). Investigations in healthy participants successfully applied LC MRI to map the spatial extent of the central noradrenergic nucleus in standard space (Betts et al., 2017; Dahl et al., 2019; Keren et al., 2009; Liu et al., 2019; Tona et al., 2017; Ye et al., 2021), paving the way for topographical cross-study comparisons. However, estimates of locus coeruleus' dimensions and localizations show a sizeable variance across publications (range of agreement: 48-94 \%; cf. Dahl et al., 2019; Liu et al., 2019; Ye et al., 2021; or even 1-40 \% using a different methodology, Mäki-Marttunen \& Espeseth, 2020). Such lack of consensus considerably limits the replicability of findings and impedes scientific progress.

Thus, the present study pursued two main goals: First, we aimed at improving the reliability and validity of MR-based LC detection. Leveraging a meta-analytical approach, we aggregated across previously published maps of the LC (Betts et al., 2017; Dahl et al., 2019; Keren et al., 2009; Liu et al., 2019; Tona et al., 2017; Ye et al., 2021) to derive a biologically plausible volume of interest (meta mask) that shows high agreement across investigations. Second, we aimed at determining whether MR-indexed LC integrity can serve as marker for noradrenergic degeneration in early-onset ADAD. To this end, we applied the newly 
medRxiv preprint doi: https://doi.org/10.1101/2020.11.16.20232561; this version posted February 2, 2021. The copyright holder for this preprint (which was not certified by peer review) is the author/funder, who has granted medRxiv a license to display the preprint in It is made available under a CC-BY-NC-ND 4.0 International license.

120 generated meta mask to an independent clinical sample to semi-automatically extract MR-

121 indexed LC integrity across the rostrocaudal extent of the nucleus (cf. Dahl et al., 2019). We

122 specifically focused on a sample of participants with or known to be at-risk for rare mutations

123 in genes causing ADAD (Presenilin-1 protein gene [PSEN1]; Amyloid- $\beta$ Precursor Protein

124 gene [APP]; Goate et al., 1991; Murrell et al., 2006; Yescas et al., 2006). In addition, using an

125 independent sample of banked post-mortem neuropathological specimens, we characterized

126 changes occurring in the LC in persons dying with the A431E mutation in PSEN1 relative to

127 controls. We hypothesized that middle to rostral MR-indexed LC integrity would be lower in

128 living symptomatic participants relative to healthy matched controls, corroborating earlier

129 post-mortem findings (in LOAD; Lyness et al., 2003). Similarly, post-mortem LC specimens

130 were hypothesized to show signs of neurodegeneration in ADAD relative to controls. Finally,

131 we predicted MR-indexed LC integrity would be associated with cortical tau burden

132 (Chalermpalanupap et al., 2018), as assessed using positron emission tomography (PET), and

133 attention and memory performance (Dahl et al., 2019; Elman et al., 2020; Liu et al., 2020). 
medRxiv preprint doi: https://doi.org/10.1101/2020.11.16.20232561; this version posted February $2,2021$. The copyright holder for this preprint (which was not certified by peer review) is the author/funder, who has granted medRxiv a license to display the preprint in It is made available under a CC-BY-NC-ND 4.0 International license.

LOWER LOCUS COERULEUS INTEGRITY IN ALZHEIMER'S

Results

135

\section{Aggregating across published locus coeruleus maps yields high confidence meta mask}

Previously published masks of the LC (Betts et al., 2017; Dahl et al., 2019; Keren et al., 2009; Liu et al., 2019; Tona et al., 2017; Ye et al., 2021) were averaged voxel-per-voxel to generate an unthresholded overlay $\left(L C_{\text {aggregate }}\right)$. The $L C_{\text {aggregate }}$ demonstrated a core of voxels that, across publications, were consistently judged to belong to the LC (see dark-blue areas in Figure 1), surrounded by a cloud of ambiguous, low-agreement voxels (see yellow areas in Figure 1). Topographically, consensus was lowest in most rostral and caudal areas (see inlay in Figure 1).

Pruning low-agreement voxels yielded a high-confidence LC volume of interest

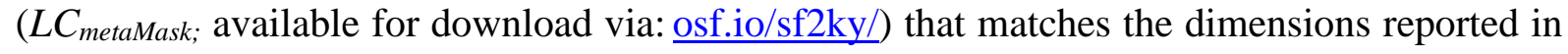
post-mortem investigations (Fernandes et al., 2012) and allows assessment of the accuracy of previously published masks.
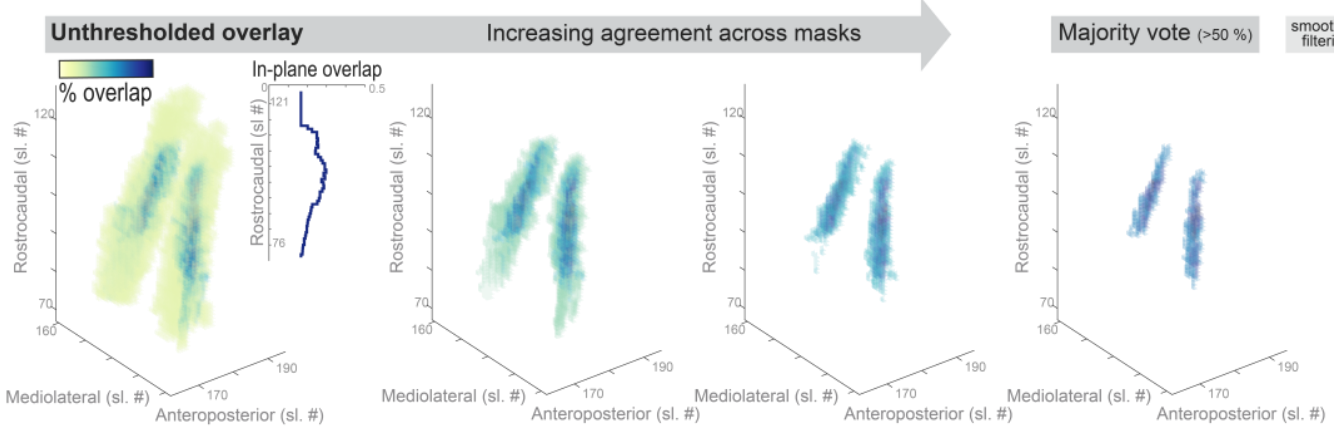

Figure 1. Aggregating across published locus coeruleus (LC) maps yields high confidence meta mask. Left. Unthresholded voxel-by-voxel average across published LC masks. Areas with voxels that are consistently judged to belong to the LC are shown in dark blue while low agreement areas are shown in yellow. Inlay. Agreement across masks (averaged across voxels in-plane) is lowest in most rostral and caudal regions. Middle. Pruning low agreement areas isolates a core of high confidence voxels. Right. Smoothing and filtering the thresholded overlay yields a biologically plausible LC volume of interest (rostrocaudal extent of $14 \mathrm{~mm}$; volume of $74 \mathrm{~mm}^{3}$ [592 voxels]), corresponding well with earlier post-mortem reports (Fernandes et al., 2012). Sl. \#, slice number in MNI 152 lin $(0.5 \mathrm{~mm})$ space; The LC meta mask is available for download via: osf.io/sf $2 \mathrm{ky} /$ ). 
medRxiv preprint doi: https://doi.org/10.1101/2020.11.16.20232561; this version posted February 2, 2021. The copyright holder for this preprint (which was not certified by peer review) is the author/funder, who has granted medRxiv a license to display the preprint in It is made available under a CC-BY-NC-ND 4.0 International license

LOWER LOCUS COERULEUS INTEGRITY IN ALZHEIMER'S

159

160

161

162

163

164

165

166

167

168

169

170

171

172

173

174 valuable information (i.e., is not redundant with previous masks).

\section{Accuracy of previously published locus coeruleus masks} (see Figure 2). of the tested masks, however, exceeded an accuracy rating of $\frac{2}{3}$, indicating that, by

Once a high-confidence LC volume of interest $\left(L C_{\text {metaMask }}\right)$ was generated, published masks were evaluated regarding their specificity and sensitivity. That is, we assessed (1) how many voxels judged by a given mask as belonging to the locus coeruleus were part of the $L C_{\text {metaMask, }}$ and (2) what percentage of the $L C_{\text {metaMask }}$ was included in each individual mask.

The mean across specificity and sensitivity was taken as accuracy measure to rank the masks

The masks that were computed based on the largest samples (cf. Table 1; Dahl et al., 2019; Liu et al., 2019) demonstrated the highest accuracy. Concerning specificity and sensitivity, the two masks appeared almost as mirror images. That is, the volume of interest published by Liu and colleagues evinced a high sensitivity at the cost of a relatively lower specificity (i.e., it included also non-LC voxels), while the situation was reversed for the mask by Dahl and colleagues (in line with it mapping peak LC coordinates; Dahl et al., 2019).

Notably, the two masks themselves show a high agreement (94\%; Liu et al., 2019). Ye and colleagues tested a smaller sample, albeit with a higher field strength $(7 \mathrm{~T})$ to generate their volume of interest which appears to strike a balance between sensitivity and specificity. None aggregating across publications, the $L C_{\text {metaMask }}$ forms a volume of interest that conveys 
medRxiv preprint doi: https://doi.org/10.1101/2020.11.16.20232561; this version posted February 2, 2021. The copyright holder for this preprint (which was not certified by peer review) is the author/funder, who has granted medRxiv a license to display the preprint in perpetuity.

It is made available under a CC-BY-NC-ND 4.0 International license

LOWER LOCUS COERULEUS INTEGRITY IN ALZHEIMER'S

Liu et al. Dahl et al. Ye et al. Tona et al. Betts et al. Keren et al.
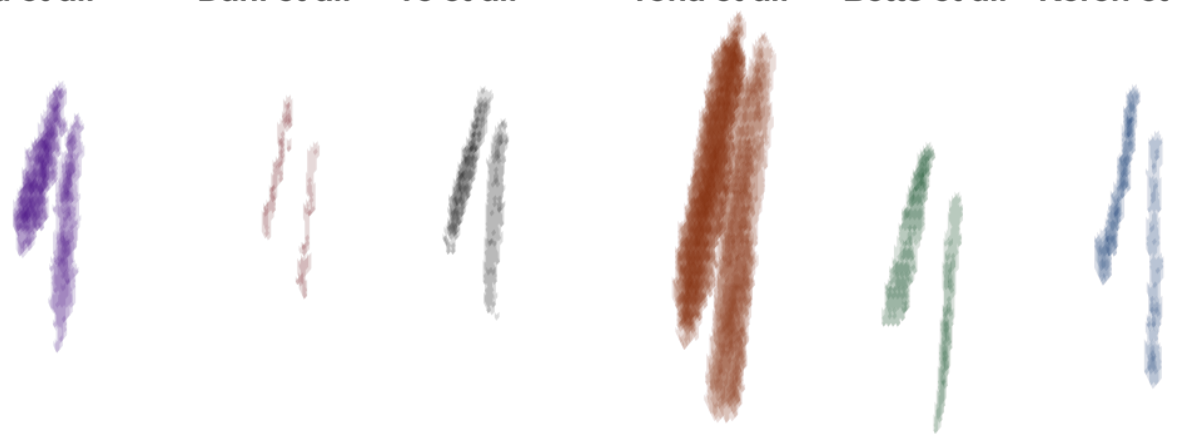

Specificity (\% of individual mask in meta mask)
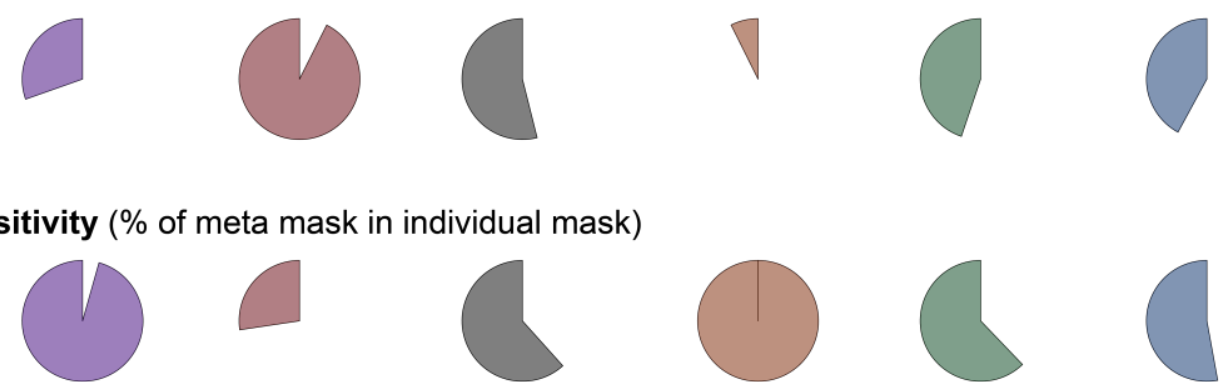

Sensitivity (\% of meta mask in individual mask)
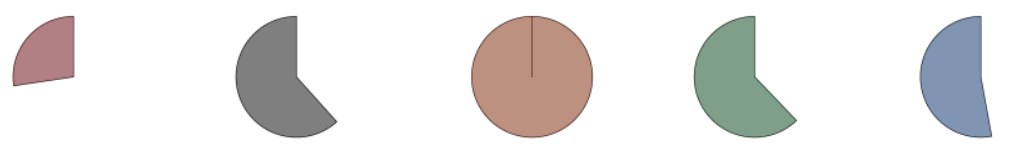

\section{Mean}
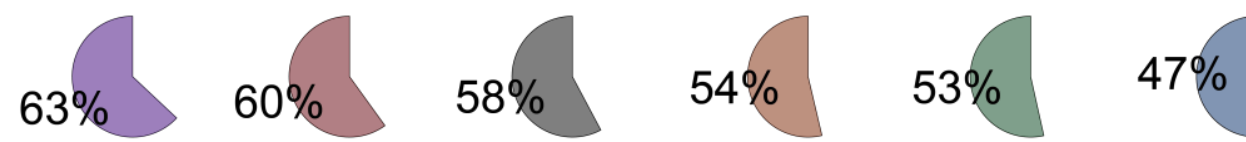

180 Figure 2. Accuracy of previously published locus coeruleus (LC) masks. Binarized masks in standard space (MNI 152, lin; top row) are ranked based on their accuracy (mean across specificity and sensitivity). Specificity expresses the percentage of a given mask that is included in the LCmetaMask whereas sensitivity denotes the percentage of the LCmetaMask that is part of each mask. For access to the individual masks, please refer to Table 1 . Note that the relative position of the individual masks (top row) corresponds to their position in MNI 152 linear space; $\mathrm{x} / \mathrm{y} / \mathrm{z}$ axes are not displayed for

186 clarity. 
medRxiv preprint doi: https://doi.org/10.1101/2020.11.16.20232561; this version posted February 2, 2021. The copyright holder for this preprint (which was not certified by peer review) is the author/funder, who has granted medRxiv a license to display the preprint in It is made available under a CC-BY-NC-ND 4.0 International license.

LOWER LOCUS COERULEUS INTEGRITY IN ALZHEIMER'S

Locus coeruleus meta mask captures high intensity voxels in independent clinical sample

We aligned and pooled across brainstem scans of participants with or known to be at-

risk for ADAD mutations (cf. Dahl et al., 2019). On the group level, we observed a cluster of

191 hyperintense voxels bordering the lateral floor of the fourth ventricle (Betts, Kirilina, et al.,

2019). This LC-related hyperintensity was accurately captured by the $L C_{\text {metaMask }}$ while

excluding more medial, non-LC related high intensity voxels (see Figure 3). Taken together,

this indicates that the $L C_{\text {metaMask }}$ can be applied to independent datasets to reliably extract MR-

indexed integrity across the rostrocaudal axis.
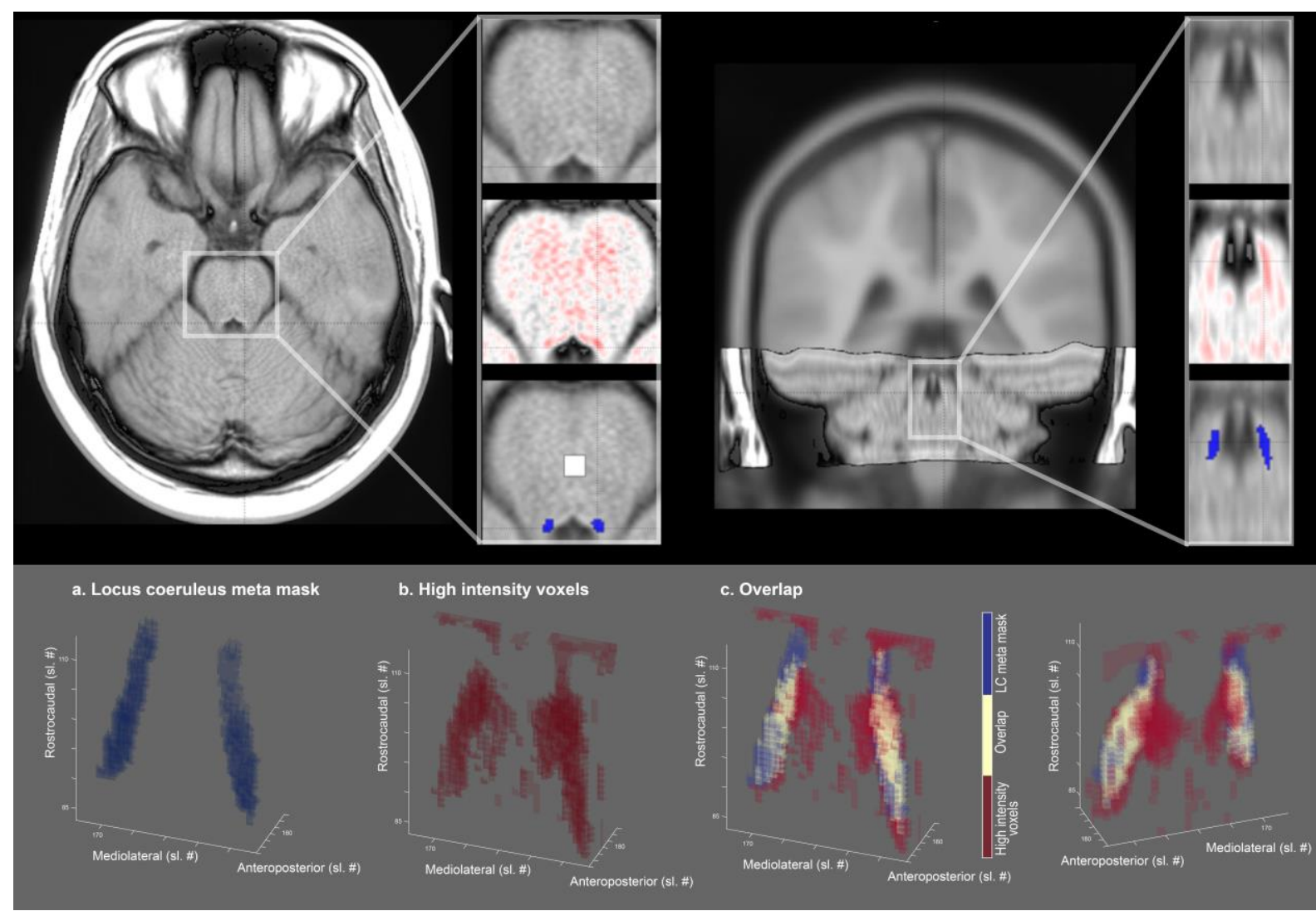

Figure 3. LC-related hyperintensity is accurately captured by meta mask. Upper row. Axial and coronal view of brainstem template overlaid on standard MNI brain. Inlays. The area surrounding the fourth ventricle is depicted with (1) a greyscale colormap and (2) a black-to-white-to-red colormap to highlight hyperintense areas. (3) LC-related hyperintensities closely overlap with the LC meta mask (blue overlay; white overlay, pontine reference region). Lower row. 3-D representation of (a) the LC meta mask, (b) above-average intensity voxels, and (c) their overlap from a front and back view. Sl. \#, slice number in MNI 152 linear $(0.5 \mathrm{~mm})$ space; LC, locus coeruleus. Right hemisphere is plotted on the left. 
medRxiv preprint doi: https://doi.org/10.1101/2020.11.16.20232561; this version posted February $2,2021$. The copyright holder for this preprint (which was not certified by peer review) is the author/funder, who has granted medRxiv a license to display the preprint in It is made available under a CC-BY-NC-ND 4.0 International license.

LOWER LOCUS COERULEUS INTEGRITY IN ALZHEIMER'S

Lower MR-indexed locus coeruleus integrity in autosomal-dominant Alzheimer's disease

208 (Keren et al., 2015) — across cognitively normal and symptomatic participants, we observed

209 reliably lower intensity in the patient group (Wilcoxon rank sum test, $Z=-2.177 ; p=0.03$;

210 see Figure 4). This difference was most pronounced in middle-rostral segments of the nucleus

211 that project to the mediotemporal lobe (Wilcoxon rank sum test of group differences in rostral

212 vs. caudal segment; $Z=-2.816 ; p=0.005$; see Figure 4). Among carriers of ADAD

213 mutations, closer proximity to the mutation-specific median age of dementia diagnosis-

214 termed adjusted age — was associated with lower LC ratios (mean correlation coefficient

215 across 1,000,000 bootstraps: rho $=-0.726 ; p=0.047$; see Figure 4). Taken together,

216 corroborating earlier post-mortem work (in LOAD; Lyness et al., 2003), we observed lower

217 MR-indexed LC integrity in middle-rostral segments of the nucleus, potentially indicating

218 noradrenergic neurodegeneration.

a. Lower LC intensity in ADAD

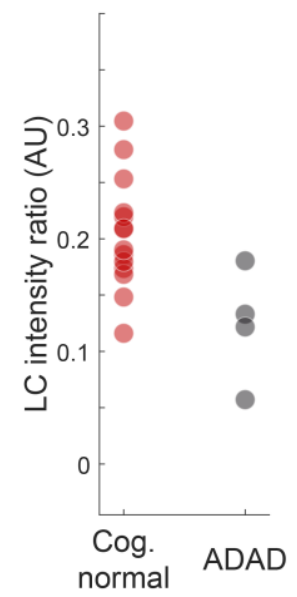

b. LC differences are rostrally accentuated

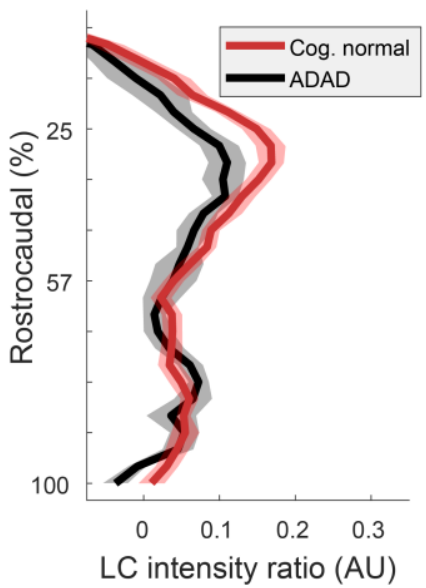

c. LC is associated with age of dementia onset

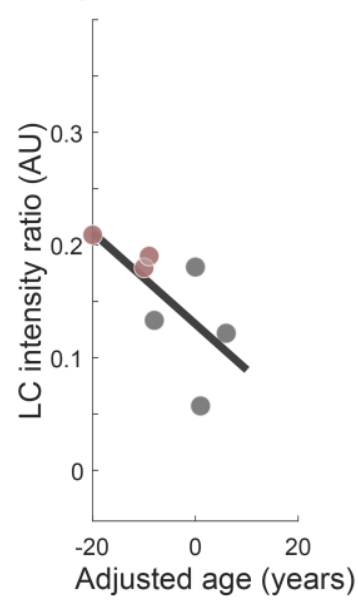

Figure 4. Lower LC intensity ratios in autosomal-dominant Alzheimer's disease (ADAD). a. Symptomatic participants show lower overall LC intensity ratios relative to cognitively normal controls $(Z=-2.177 ; p=0.03)$. b. Group differences are most pronounced in middlerostral segments of the LC (plotted on the y-axis; $Z=-2.816 ; p=0.005$; shaded areas indicate \pm 1 standard error of the mean $[\mathrm{SEM}])$. c. Closer proximity to the mutation-specific median age of dementia diagnosis (adjusted age) is associated with lower overall LC ratios (mean correlation coefficient across $1,000,000$ bootstraps: $r h o=-0.726 ; p=0.047)$. LC, locus coeruleus; Cog. normal, cognitively unimpaired participants. 
medRxiv preprint doi: https://doi.org/10.1101/2020.11.16.20232561; this version posted February 2, 2021. The copyright holder for this preprint (which was not certified by peer review) is the author/funder, who has granted medRxiv a license to display the preprint in It is made available under a CC-BY-NC-ND 4.0 International license

MR-indexed locus coeruleus integrity is associated with cortical tau burden

Previous animal research suggests that noradrenergic neurodegeneration may

231 exacerbate neural decline and contribute to Alzheimer's pathogenesis (Chalermpalanupap et

232 al., 2018; Rorabaugh et al., 2017). Thus, we next tested whether LC intensity would be

233 associated with cortical tau burden, a hallmark of AD.

Across cortical regions (Desikan et al., 2006), symptomatic participants demonstrated

higher flortaucipir SUVR (see Figure 5). Importantly, leveraging a multivariate statistical approach (partial least squares correlation [PLSC]; Krishnan et al., 2011), we revealed a topographical pattern of LC-related tau pathology ( $p=0.037$; see Figure 5). That is, we extracted a latent variable (latent PLS score) that optimally captures the multivariate association between participants' LC intensity and regional tau burden $(r=0.54[95 \%$

240 confidence interval (CI): $0.167,0.806]$; lower LC intensity was associated with higher

241 flortaucipir SUVR). Especially tau pathology in occipito-temporo-parietal regions contributed

242 to this latent variable, as indicated by reliable bootstrap ratios (BSR; $<-3$; see Figure 5; BSR

243 can be interpreted akin to Z-values; please note that we opted for a conservative threshold [-

2443 ] due to the large number of cortical ROI). In sum, in line with research in genetically

245 modified animals (Chalermpalanupap et al., 2018; Rorabaugh et al., 2017), we observed a

246 prominent association between in-vivo proxies of LC integrity and tau pathology. 
medRxiv preprint doi: https://doi.org/10.1101/2020.11.16.20232561; this version posted February $2,2021$. The copyright holder for this preprint (which was not certified by peer review) is the author/funder, who has granted medRxiv a license to display the preprint in It is made available under a CC-BY-NC-ND 4.0 International license .

a. More tau pathology in ADAD
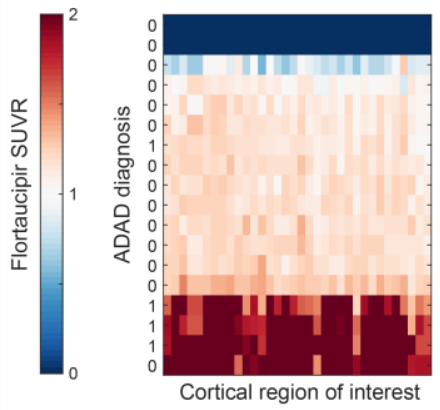

b. LC-related regional tau pathology

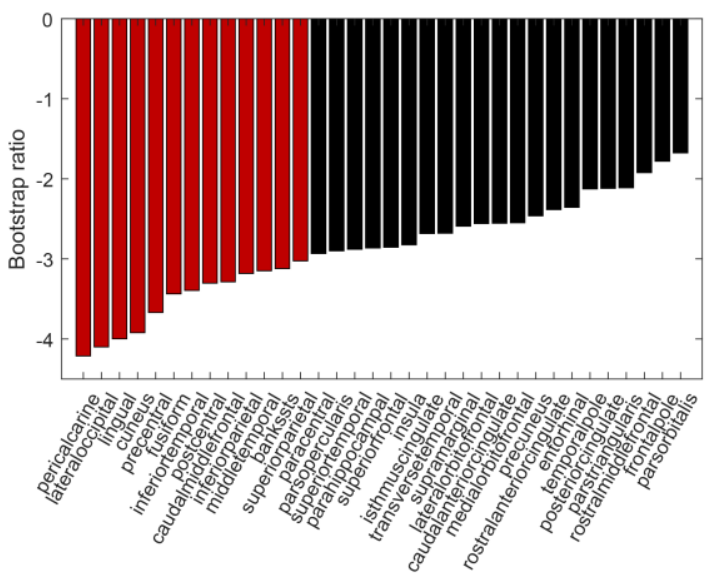

c. Multivariate tau profile is associated with LC

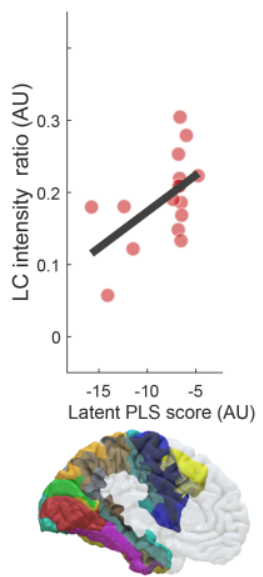

Figure 5. Lower LC intensity is associated with tau burden in posterior brain regions. a. Symptomatic participants show higher flortaucipir standardized uptake value ratios (SUVR) across most cortical regions relative to cognitively normal controls (missing PET data for two participants [dark blue bars]). b. Contribution of individual cortical regions of interest to a partial least squares (PLS) latent variable indexing LC-related tau pathology (Bootstrap ratios $<-3$ are considered reliable). c. Scatter plot depicting the relation between latent PLS scores and LC intensity ( $p=0.037 ; r=0.54$ [95 \% CI: 0.167, 0.806]). LC, locus coeruleus; ADAD, autosomal-dominant Alzheimer's disease.

\section{MR-indexed locus coeruleus integrity is associated with cognitive deficits}

Finally, we set out to test the behavioral relevance of our in-vivo proxy of LC

integrity. Norepinephrine release from the LC is strongly implicated in the modulation of

attentional and mnemonic processing (Berridge \& Waterhouse, 2003; Dahl, Mather, Sander, \& Werkle-Bergner, 2020; Lee et al., 2018; Sara, 2009). Accordingly, recent imaging studies reported positive associations between LC intensity and cognition in healthy aging (Dahl et al., 2019; Hämmerer et al., 2018; Liu et al., 2020). However, whether this relation extends to ADAD of young onset is currently unknown.

Across a range of cognitive tasks, we detected worse cognitive abilities and higher dementia symptoms in the ADAD group relative to controls (see Figure 6). Reliable group differences (Wilcoxon rank sum test; $Z<-1.96 \mid Z>1.96$ ) were observed for screening instruments (the Montreal Cognitive Assessment [MoCA, Nasreddine et al., 2005]; the

271 Cognitive Abilities Screening Instrument [CASI; Teng et al., 1994], and the Washington 
medRxiv preprint doi: https://doi.org/10.1101/2020.11.16.20232561; this version posted February 2, 2021. The copyright holder for this preprint (which was not certified by peer review) is the author/funder, who has granted medRxiv a license to display the preprint in It is made available under a CC-BY-NC-ND 4.0 International license.

272 University Clinical Dementia Rating Scale [CDR; measure: sum of boxes; cf. O’Bryant et al., 273 2008]). In addition, symptomatic participants performed significantly worse on the Spanish

274 English Verbal Learning Test (SEVLT; measures: average performance over learning trials 275 and delayed recall; González, Mungas, \& Haan, 2002), in line with reports of verbal learning

276 tests to convey information about participants' current and future cognitive status (Albert,

277 Moss, Tanzi, \& Jones, 2001; Belleville, Fouquet, Hudon, Zomahoun, \& Croteau, 2017;

278 Moradi, Hallikainen, Hänninen, \& Tohka, 2017; Schoenberg et al., 2006). We applied a partial least squares correlation (PLSC) to isolate the pattern of cognitive 280 impairment reliably linked to MR-indexed LC integrity. Our analyses isolated a single latent 281 variable $(p=0.016)$ that optimally expresses the multivariate association between

282 participants' LC intensity and cognitive performance ( $r=0.728$ [95 \% CI: 0.408, 0.888]). All

283 cognitive tasks that were sensitive to distinguish symptomatic from cognitively normal 284 participants contributed reliably to this latent variable (bootstrap ratios $[\mathrm{BSR}]<-1.96 \mid \mathrm{BSR}>$ 285 1.96; see Figure 6). To conclude, across a range of neuropsychological tests, higher MR286 indexed LC integrity was observed in participants with unimpaired cognitive performance. 
medRxiv preprint doi: https://doi.org/10.1101/2020.11.16.20232561; this version posted February $2,2021$. The copyright holder for this preprint (which was not certified by peer review) is the author/funder, who has granted medRxiv a license to display the preprint in It is made available under a CC-BY-NC-ND 4.0 International license

\section{a. Lower cognition in ADAD}

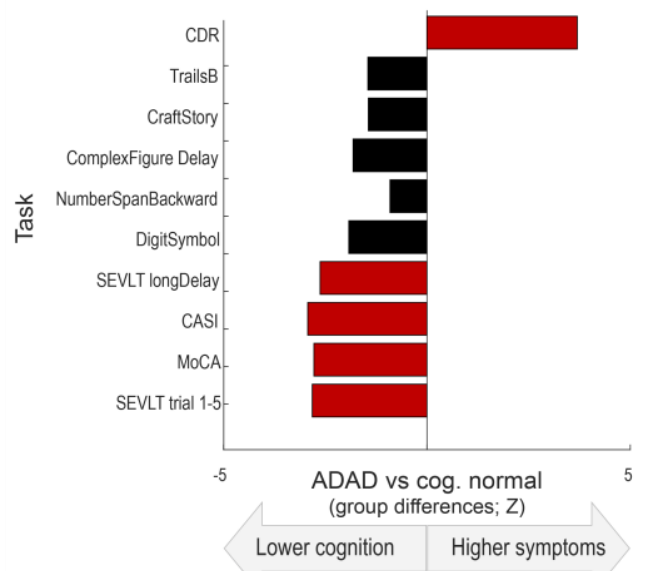

b. LC-related cognitive tasks

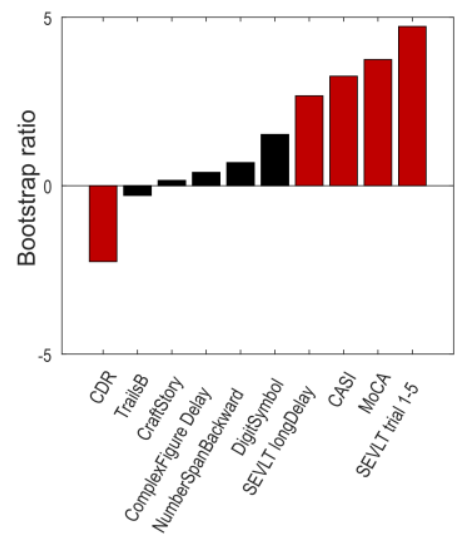

c. Multivariate cognitive profile is associated with LC

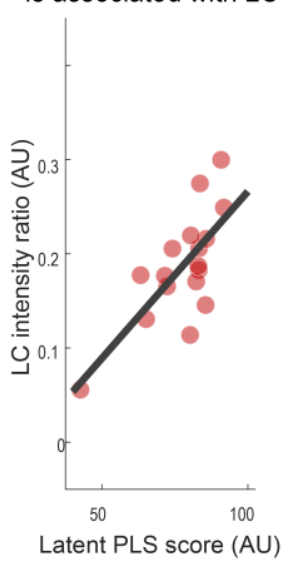

Figure 6. Lower LC intensity is associated with cognitive deficits. a. Symptomatic participants show lower cognitive performance as indicated from screening instruments for mild cognitive impairment and dementia (Clinical Dementia Rating Scale, sum of boxes [CDR]; Cognitive Abilities Screening Instrument [CASI]; Montreal Cognitive Assessment [MoCA]) as well as the Spanish English Verbal learning task (SEVLT). b. Contribution of individual neuropsychological tests to a partial least squares (PLS) latent variable indexing LC-related cognitive deficits (Bootstrap ratios $<-1.96$ and $>1.96$ are considered reliable). c. Scatter plot depicting the relation between latent PLS scores and LC intensity $(p=0.016 ; r=$ 0.728 [95 \% CI: 0.408, 0.888]). LC, locus coeruleus; ADAD, autosomal-dominant Alzheimer's disease. For references to the cognitive tasks, please refer to the main text.

\section{Neuropathological findings in the locus coeruleus}

Descriptions of the neuropathological changes occurring in the brainstem in ADAD are scarce. To characterize the pathology underlying the LC signal on MRI in ADAD, LC histopathology was compared between four carriers of the A431E mutation in PSEN1 (aged 39-59 years, 2 9), including one person homozygous for the A431E mutation (Parker et al., 2019), and five neurologically normal controls (aged 37-58 years, 2 ). . All A431E mutation carriers demonstrated severe loss of LC neurons and background astrogliosis by GFAP relative to controls. The remaining LC neurons from the A431E mutant carriers demonstrated a severe loss of neuromelanin and reactivity (see Figure 7). AT8 staining showed neuritic changes in all A431E mutation carriers with three of four showing neurofibrillary tangle formation. On staining with $4 \mathrm{G} 8$, three mutation carriers showed diffuse extracellular neuritic 
medRxiv preprint doi: https://doi.org/10.1101/2020.11.16.20232561; this version posted February $2,2021$. The copyright holder for this preprint (which was not certified by peer review) is the author/funder, who has granted medRxiv a license to display the preprint in perpetuity perpetuity. 4.0 International license

plaques. Alpha synuclein staining did not reveal any Lewy body pathology in any samples.

313 Immunostaining using antibodies against 4-repeat tau (RD4) and 3-repeat-tau (RD3) showed

314 positivity for both isoforms.

\section{Hematoxylin \& Eosin, 10x}

A431E

heterozygote

$(45-50$ years, + )

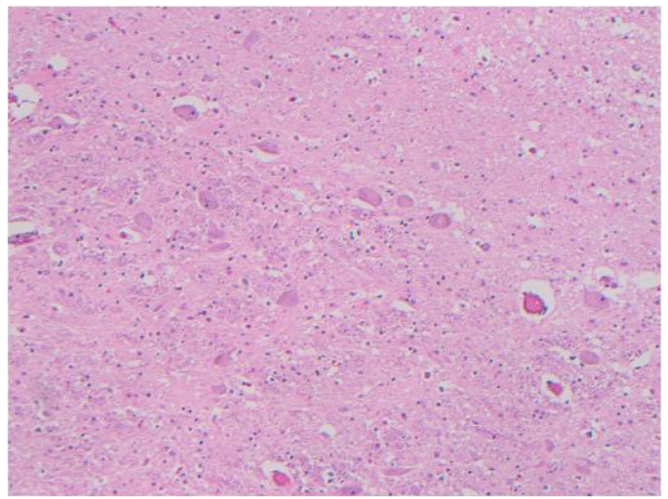

Anti-Tau(AT8) IHC, 10x

A431E homozygote $(35-40$ years, $\hat{\jmath})$

\section{Control}

(45-50 years, ㅇ)
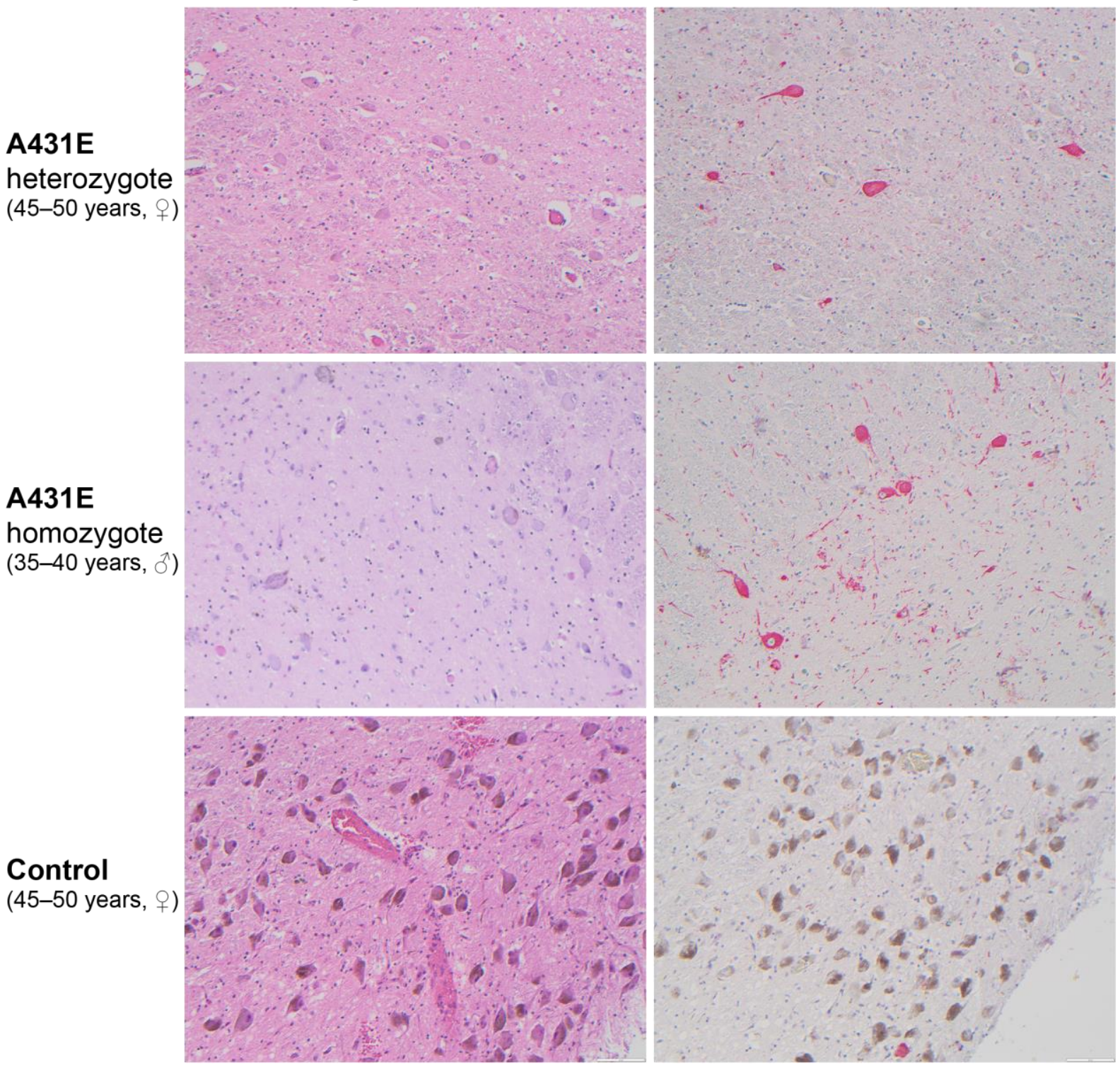

Figure 7. Neuropathological findings in the locus coeruleus of a 45-50 year old woman heterozygous for the A431E mutation in PSEN1, a 35-40 year old man homozygous for the A431E mutation in PSEN1, and a normal control (45-50 year old). Hematoxylin and Eosin (H\&E) staining shows profound drop-out of neurons in the PSEN1 mutation carriers compared to control. Neurons within carriers lack neuromelanin and show loss of pigment; whereas, neurons within control show robust pigmentation and neuromelanin expression. Immunostained slides with anti-tau (AT8) antibodies using red chromagen demonstrate neurofibrillary tangles within neurons and the presence of many tau positive threads in PSEN1 mutation carriers with only a very rare single neurofibrillary tangle observed in normal control (lower portion of image). 
medRxiv preprint doi: https://doi.org/10.1101/2020.11.16.20232561; this version posted February 2, 2021. The copyright holder for this preprint (which was not certified by peer review) is the author/funder, who has granted medRxiv a license to display the preprint in It is made available under a CC-BY-NC-ND 4.0 International license .

LOWER LOCUS COERULEUS INTEGRITY IN ALZHEIMER'S

\section{Discussion}

Animal and post-mortem research indicates that the brain's noradrenergic system plays a central role in the pathogenesis of Alzheimer's disease (Braak et al., 2011; Weinshenker, 2018). In vivo investigations, however, have long been hindered by challenges in reliable non-invasive LC assessments (Astafiev et al., 2010; Keren et al., 2009). While initial intriguing in vivo studies in late-onset Alzheimer's are underway (LOAD; e.g., Betts, Cardenas-Blanco, et al., 2019; Jessen et al., 2018), unequivocally distinguishing age- from disease-related LC alterations is difficult on this basis (Dahl et al., 2019; Liu et al., 2019). Focusing instead on types of dementia developing earlier in life provides a unique window into the mechanisms driving Alzheimer's development (ADAD; Bateman et al., 2012; Jacobs, Becker, et al., 2019; Ringman, 2005).

Leveraging a meta-analytical approach, we first synthesized LC localizations and dimensions across previously published studies to improve the reliability and validity of MRbased LC detection. In a second step, we applied this newly generated volume of interest to determine whether MR-indexed LC integrity can serve as marker for noradrenergic degeneration in ADAD and verified this pathology using post-mortem samples. Our analyses isolated a cluster of high-confidence voxels that (1) is consistently identified as LC across published studies and (2) corresponds well to post-mortem reports (Fernandes et al., 2012). Next, exploiting this refined spatial characterization we semiautomatically extracted intensity data in an independent sample of participants with or known to be at-risk for mutations in genes associated with ADAD. We revealed lower MR-indexed LC integrity in symptomatic mutation carriers. Group differences were most pronounced in middle to rostral segments of the LC (Ehrenberg et al., 2017; Lyness et al., 2003) and scaled with proximity to the mutation-specific median age of dementia diagnosis (Ryman et al., 2014). Beyond that, lower overall LC intensity was linked to higher tau burden in posterior brain regions (Chalermpalanupap et al., 2018) and worse cognitive performance across 
medRxiv preprint doi: https://doi.org/10.1101/2020.11.16.20232561; this version posted February 2, 2021. The copyright holder for this preprint (which was not certified by peer review) is the author/funder, who has granted medRxiv a license to display the preprint in It is made available under a CC-BY-NC-ND 4.0 International license . LOWER LOCUS COERULEUS INTEGRITY IN ALZHEIMER'S

352

353

354

355

several neuropsychological tests (Dahl et al., 2019; Liu et al., 2020). Taken together, our finding of diminished LC integrity in ADAD suggests a prominent role of the noradrenergic system in this neurodegenerative disease.

\section{Aggregating across published locus coeruleus maps yields high confidence meta mask}

Imaging of small brainstem structures that are not visible using conventional MR sequences is notoriously challenging (for discussions, see Astafiev et al., 2010; Keren et al., 2009) and warrants a close alignment of individual scans (for recommendations, see Betts, Kirilina, et al., 2019; Liu et al., 2017). Here we used Advanced Normalization Tools (ANTs; Avants et al., 2011, 2009) for brainstem normalization. ANTs is becoming increasingly recognized as a powerful tool for accurate coregistrations - it has won several internationally recognized medical image processing challenges (e.g., Klein et al., 2009 for a full list see github.com/ANTsX/ANTs) and was used in all of the currently best ranked LC mapping studies (3/3, [relative to 1/3 of the remaining studies]; Dahl et al., 2019; Liu et al., 2019; Ye et al., 2021).

Besides normalization, LC mapping studies employing larger sample sizes and a higher MR-field strength evinced a higher accuracy, as indicated by spatial congruence with the meta mask (Dahl et al., 2019; Liu et al., 2019; Ye et al., 2021). We hope that by sharing an unbiased, biologically-plausible LC volume of interest that is based on more than 1,000 participants and all commonly used sequence types (FSE, MT, FLASH; see Table 1) we assist future functional and structural imaging studies in classifying brainstem effects (this LC meta mask is available for download via osf.io/sf2ky/).

\section{Lower MR-indexed locus coeruleus integrity in autosomal-dominant Alzheimer's disease}

Applying the newly generated LC meta mask to an independent clinical sample, we demonstrate its utility for accurately extracting intensity information across the rostrocaudal 
medRxiv preprint doi: https://doi.org/10.1101/2020.11.16.20232561; this version posted February $2,2021$. The copyright holder for this preprint (which was not certified by peer review) is the author/funder, who has granted medRxiv a license to display the preprint in It is made available under a CC-BY-NC-ND 4.0 International license .

LOWER LOCUS COERULEUS INTEGRITY IN ALZHEIMER'S

extent of the nucleus. We observed lower middle-rostral LC intensity in symptomatic carriers of ADAD-causing mutations. This finding is consistent with post-mortem reports of substantial noradrenergic neurodegeneration in LOAD (Lyness et al., 2003). Some previous post-mortem studies in ADAD also noted disproportionate depigmentation and neuronal loss in the LC (Janssen et al., 2000; Snider et al., 2005) which we verified in four persons dying with the A431E mutation in PSEN1. In vivo imaging studies are in general agreement with the histological findings and indicate lower LC contrast in LOAD patients (Betts, CardenasBlanco, et al., 2019; Dordevic et al., 2017; Takahashi et al., 2015). To date there is only a single imaging study focusing on early-onset Alzheimer's (ADAD; Jacobs, Becker, et al., 2019), albeit in non-symptomatic mutation carriers (i.e., at a preclinical stage). Our

388 observation that LC intensity scaled with proximity of dementia onset (adjusted age) across non-symptomatic and symptomatic mutation carriers matches a negative age association in mutation carriers reported by Jacobs and colleagues (2019) and might indicate a progressive

391 deterioration. In conjunction with prior post-mortem validations of LC MRI (Keren et al., 2015; Cassidy et al., 2019) and decreased cell counts in LOAD (Lyness et al., 2003), our post393 mortem validation of decreased cell counts in the LC in ADAD are indicative of 394 noradrenergic neurodegeneration in ADAD.

\section{MR-indexed locus coeruleus integrity is associated with cortical tau burden}

Leveraging a multivariate statistical approach, we further revealed a pattern of LCrelated tau pathology that was most pronounced in posterior brain regions (cf. Jacobs, Becker,

399 et al., 2019). This observation supports the notion that loss of noradrenergic neurons may exacerbate the severity of other Alzheimer's hallmarks, like tau pathology (Chalermpalanupap et al., 2018). The LC is one of the first brain regions in which aberrant tau can be detected at relatively early ages (i.e., the first decades of life; Braak et al., 2011). The accumulation of 
medRxiv preprint doi: https://doi.org/10.1101/2020.11.16.20232561; this version posted February 2, 2021. The copyright holder for this preprint (which was not certified by peer review) is the author/funder, who has granted medRxiv a license to display the preprint in

404 which in turn promotes tau release and spread along LC' widespread axonal pathways

405 (Chalermpalanupap et al., 2017; Weinshenker, 2018). While tau gradually propagates through

406 cortical regions (categorized as Braak stages), noradrenergic neurons first shrink in size and

407 then degenerate (Ehrenberg et al., 2017; Kelly et al., 2017; Theofilas et al., 2017). The frank

408 decline of noradrenergic cells is preceded by a period of dysfunctional neurotransmission in

409 LC's terminal regions like the mediotemporal lobe (Weinshenker, 2018). Thus, the negative

410 association between in vivo proxies for LC integrity and tau burden may signify a more

411 advanced Alzheimer's disease stage including noradrenergic neurodegeneration and wide-

412 spread tau pathology.

MR-indexed locus coeruleus integrity is associated with cognitive deficits

Finally, we found evidence for an association between MR-indexed LC integrity and

cognitive performance across several neuropsychological tests. Noradrenergic

neuromodulation has been implicated in a range of cognitive functions, prominently including attention and memory (Berridge \& Waterhouse, 2003; Bouret \& Sara, 2005; Corbetta, Patel, \& Shulman, 2008; Mather, Clewett, Sakaki, \& Harley, 2016; Sara, 2009). In particular, mediated via $\beta$-adrenoceptors, norepinephrine release promotes long-term-potentiation in the

421 hippocampus - a key determinant of synaptic plasticity and memory (O’Dell, Connor,

422 Guglietta, \& Nguyen, 2015). Recent optogenetic research moreover indicates a causal role of

423 LC activity in memory acquisition and consolidation, potentially supported by co-release of

424 dopamine (Duszkiewicz, McNamara, Takeuchi, \& Genzel, 2019; Takeuchi et al., 2016;

425 Uematsu et al., 2017; Wagatsuma et al., 2018). Consistent with these observations in animals, recent in vivo human research demonstrated an association between MR-indexed LC integrity

427 and memory performance in healthy aging (Dahl et al., 2019; Elman et al., 2020; Hämmerer 428 et al., 2018; Liu et al., 2020). Extending evidence from healthy populations, we here confirm

429 the behavioral relevance of MR-indexed LC integrity in tracking cognitive decline in a 
medRxiv preprint doi: https://doi.org/10.1101/2020.11.16.20232561; this version posted February $2,2021$. The copyright holder for this preprint (which was not certified by peer review) is the author/funder, who has granted medRxiv a license to display the preprint in It is made available under a CC-BY-NC-ND 4.0 International license

LOWER LOCUS COERULEUS INTEGRITY IN ALZHEIMER'S

430 clinical sample. Neuropsychological tests that proved sensitive to distinguish patients from

431 controls were reliably linked to LC integrity (González et al., 2002; Nasreddine et al., 2005;

432 O'Bryant et al., 2008; Teng et al., 1994). In line with reports indicating verbal learning tests as

433 effective early markers of Alzheimer's pathology (Albert et al., 2001; Belleville et al., 2017;

434 Moradi et al., 2017; Schoenberg et al., 2006), verbal learning and memory showed the closest

435 link to LC integrity (cf. Dahl et al., 2019, for analogous results in later life). Taken together,

436 our findings suggest that noradrenergic neurotransmission supports memory performance

437 whereas dysfunctions therein are associated with Alzheimer's related cognitive decline.

\section{Limitations and conclusions}

Some limitations should be noted. First, the contrast mechanisms underlying LC-

441 MRI constitute an active area of research (for a discussion, see Betts, Kirilina, et al., 2019)

442 and future studies may help determine what precise physiological processes are reflected in

443 MR-contrast differences. Second, as a cross-sectional observational study, it is not possible to

444 conclude a causative relationship between loss of LC integrity and cognitive symptoms and 445 deposition of abnormal tau in persons with ADAD. Finally, with a prevalence of about 5 cases

446 per 100,000 persons at risk, ADAD is a rare disease (Campion et al., 1999) accounting for less 447 than $1 \%$ of all Alzheimer's cases (Bateman et al., 2011). All but one ADAD mutation carriers 448 in the current study had the same mutation in PSEN1 (A431E) which has specific features

449 (e.g., co-occurring spastic paraparesis and possibly atypical posterior-predominant tau 450 deposition) that may limit generalizability of the current findings. While providing insights

451 into the pathogenesis of Alzheimer's largely disentangled from factors associated with aging, 452 the presented findings need to be corroborated by longitudinal evidence in larger samples 453 (Lindenberger et al., 2011). In conclusion, we applied a meta-analytical approach to advance the reliability and 455 validity of MR-based LC detection. Using non-invasive in vivo proxies, we revealed lower 
medRxiv preprint doi: https://doi.org/10.1101/2020.11.16.20232561; this version posted February 2, 2021. The copyright holder for this preprint (which was not certified by peer review) is the author/funder, who has granted medRxiv a license to display the preprint in It is made available under a CC-BY-NC-ND 4.0 International license.

456 LC integrity in symptomatic carriers of ADAD-causing mutations. Moreover, LC integrity

457 was strongly associated with cortical tau pathology and memory decline. In summary, this

458 provides support for a prominent role of the noradrenergic system in Alzheimer's disease

459 (Mather \& Harley, 2016; Weinshenker, 2018). 
medRxiv preprint doi: https://doi.org/10.1101/2020.11.16.20232561; this version posted February 2, 2021. The copyright holder for this preprint (which was not certified by peer review) is the author/funder, who has granted medRxiv a license to display the preprint in It is made available under a CC-BY-NC-ND 4.0 International license .

LOWER LOCUS COERULEUS INTEGRITY IN ALZHEIMER'S

Material and methods

461 Aggregating across published locus coeruleus maps to derive a high confidence meta

mask

Previous mapping studies used a variety of LC-sensitive MRI sequences (Turbo Spin

464 Echo [TSE; Dahl et al., 2019; Keren et al., 2009; Tona et al., 2017]; Magnetization Transfer

465 [MT; Liu et al., 2019; Ye et al., 2021]; Fast Low Angle Shot [FLASH; Betts et al., 2017]) at

466 different field strength (7 Tesla: Ye et al., 2021; 3 Tesla: all other studies) to visualize the

467 nucleus. Most investigations were conducted across younger and older adults or even within

468 lifespan samples (but see Tona et al., 2017 and Ye et al., 2021 for studies in younger and older

469 adults, respectively). After data collection, individual brainstem scans were transformed into a

470 group or standard space in which a manual (Betts et al., 2017; Liu et al., 2019; Tona et al.,

471 2017) or semi-automatic (Dahl et al., 2019; Keren et al., 2009; Ye et al., 2021) approach was

472 taken to segment the LC from surrounding tissue. While some earlier reports (Dahl et al.,

473 2019; Liu et al., 2019; Ye et al., 2021) include a comparison of a subset of the published

474 masks, to date there is no systematic evaluation of their agreement. More importantly, no

475 previous study attempted to resolve the apparent disagreement in LC dimensions and

476 localizations across publications.

In keeping with earlier analyses (Dahl et al., 2019; Liu et al., 2019; Ye et al., 2021),

478 the LC masks noted in Table 1 were used for cross-study comparisons. Before relating

479 different masks to one-another, all volumes were binarized and moved to a common space

480 (MNI-ICBM 152 linear space, $0.5 \mathrm{~mm}$ resolution), if necessary. In standard space, first an

481 unthresholded aggregate mask was generated using the following formula:

$$
L C_{\text {aggregate }}=\frac{1}{n} \sum_{i=1}^{n}(v)
$$

Whereby $n$ denotes the number of masks included in the analyses $(n=6)$ and $v$ 
medRxiv preprint doi: https://doi.org/10.1101/2020.11.16.20232561; this version posted February 2, 2021. The copyright holder for this preprint (which was not certified by peer review) is the author/funder, who has granted medRxiv a license to display the preprint in It is made available under a CC-BY-NC-ND 4.0 International license.

voxel the individual binarized masks were averaged, resulting in an aggregate mask

( $L C_{\text {aggregate; }}$ see Figure 1$)$. The generated volume, $L C_{\text {aggregate, }}$, showed a value range between 0

and 1 (complete agreement that a voxel does not/does belong to the LC, respectively) in steps

of $\frac{1}{n}$. Please note that we decided against weighing the contribution of the individual masks to the $L C_{\text {aggregate }}$ by sample size as two masks (Dahl et al., 2019; Liu et al., 2019) account for more than $80 \%$ of the total number of participants (see Table 1). Hence, the aggregate would

491 be strongly biased in favor of a subset of masks that are themselves highly spatially congruent (agreement 94\%; Liu et al., 2019).

In a second step, the aggregate mask was pruned by removing low-agreement voxels

494 until a majority vote was achieved. That is, only areas with agreement values $>50 \%$ were

495 retained (i.e., more than $\frac{1}{2} n$ masks voted for a voxel to belong to the LC). Essentially, the 496 described mask generation process is comparable to label fusion with majority voting 497 (Rohlfing, Brandt, Menzel, \& Maurer, 2004; Sabuncu, Yeo, Van Leemput, Fischl, \& Golland, 498 2010; Wang et al., 2013) .

Finally, to obtain a biologically more plausible volume, the pruned aggregate mask 500 was smoothed with a $0.1 \mathrm{~mm}$ full width at half maximum (FWHM) kernel using SPM12 501 (Penny, Friston, Ashburner, Kiebel, \& Nichols, 2007) in Matlab (The MathWorks Inc., Natick, MA, USA). Voxels exceeding a threshold of 0.05 were considered part of the LC in the meta

503 mask ( $L C_{\text {metaMask; }}$ see Figure 1$)$. The resulting mask had a rostrocaudal extent of $14 \mathrm{~mm}$ and a 504 volume of $74 \mathrm{~mm}^{3}$ (592 voxels), corresponding well with previous post-mortem findings 505 (Fernandes, Regala, Correia, \& Gonçalves-Ferreira, 2012; Tona et al., 2017). We share the generated meta mask with the scientific community via osf.io/sf2ky/ 
medRxiv preprint doi: https://doi.org/10.1101/2020.11.16.20232561; this version posted February 2, 2021. The copyright holder for this preprint (which was not certified by peer review) is the author/funder, who has granted medRxiv a license to display the preprint in It is made available under a CC-BY-NC-ND 4.0 International license.

LOWER LOCUS COERULEUS INTEGRITY IN ALZHEIMER'S

509 Table 1: Locus coeruleus masks included in comparisons

\begin{tabular}{|c|c|c|c|c|c|c|}
\hline Publication & $\begin{array}{l}\text { MRI } \\
\text { acquisition }\end{array}$ & Sample & $\begin{array}{l}\text { Locus } \\
\text { coeruleus } \\
\text { segmentaion }\end{array}$ & Mask source & $\begin{array}{l}\text { Mask } \\
\text { version }\end{array}$ & Note \\
\hline $\begin{array}{l}\text { Betts et al., } \\
2017\end{array}$ & $\begin{array}{l}3 \mathrm{~T} ; \\
\text { FLASH }\end{array}$ & $\begin{array}{l}\mathrm{N}=82 \\
\mathrm{YA} ; \mathrm{OA}\end{array}$ & Manual & $\frac{\text { https://doi.org/10.1016/ }}{\text { j.neuroimage.2017.09.042 }}$ & -- & -- \\
\hline $\begin{array}{l}\text { Dahl et al., } \\
2019\end{array}$ & $\begin{array}{l}3 \mathrm{~T} \\
\mathrm{TSE}\end{array}$ & $\begin{array}{l}\mathrm{N}=294 \\
\text { YA; OA }\end{array}$ & $\begin{array}{l}\text { Semi- } \\
\text { automatic }\end{array}$ & $\begin{array}{l}\text { https://www.mpib- } \\
\text { berlin.mpg.de/LC-Map }\end{array}$ & -- & -- \\
\hline $\begin{array}{l}\text { Keren et al., } \\
2009\end{array}$ & $\begin{array}{l}3 \mathrm{~T} ; \\
\text { TSE }\end{array}$ & $\begin{array}{l}\mathrm{N}=44 \\
\mathrm{YA}-\mathrm{OA}\end{array}$ & $\begin{array}{l}\text { Semi- } \\
\text { automatic }\end{array}$ & http://www.eckertlab.org/LC & $\begin{array}{l}1 \text { standard } \\
\text { deviation }\end{array}$ & -- \\
\hline $\begin{array}{l}\text { Liu et al., } \\
2019\end{array}$ & $\begin{array}{l}3 \mathrm{~T} \\
\mathrm{MT}\end{array}$ & $\begin{array}{l}\mathrm{N}=605 \\
\mathrm{YA}-\mathrm{OA}\end{array}$ & Manual & $\underline{\text { https://osf.io/r2bwk }}$ & -- & -- \\
\hline $\begin{array}{l}\text { Tona et al. } \\
2017\end{array}$ & $\begin{array}{l}3 \mathrm{~T} ; \\
\text { TSE }\end{array}$ & $\begin{array}{l}\mathrm{N}=17 \\
\mathrm{YA}\end{array}$ & Manual & $\frac{\text { http://www.nitrc.org/ }}{\text { projects/prob_lc_3t }}$ & -- & $\begin{array}{l}\text { Mask averaged } \\
\text { across scan } \\
\text { sessions and } \\
\text { segmentations }\end{array}$ \\
\hline $\begin{array}{l}\text { (Ye et al., } \\
2021 \text { ) }\end{array}$ & $\begin{array}{l}7 \mathrm{~T} \\
\mathrm{MT}\end{array}$ & $\begin{array}{l}\mathrm{N}=53 \\
\mathrm{OA}\end{array}$ & $\begin{array}{l}\text { Semi- } \\
\text { automatic }\end{array}$ & $\begin{array}{l}\text { https://www.nitrc.org/ } \\
\text { projects/lc_7t_prob }\end{array}$ & $\begin{array}{l}5 \% \\
\text { probability }\end{array}$ & $\begin{array}{l}\text { Mask } \\
\text { transformed from } \\
\text { MNI-ICBM } 152 \\
\text { non-linear 2009b } \\
\text { to linear space }\end{array}$ \\
\hline
\end{tabular}

Note: ${ }^{1}$ The mask by Ye and colleagues was linearly and non-linearly co-registered to MNI-ICBM 152 linear space (0.5 mm resolution) using Advanced Normalization Tools (antsRegistration). MNI-ICBM 152 linear was chosen as target space as all but one masks share this space. For co-registration, the standard brains of the respective spaces were aligned and the transformations were applied to the mask file with a nearest neighbor interpolation. The transformations from MNI $2009 \mathrm{~b}$ non-lin $\Leftrightarrow$ MNI linear are shared via osf.io/sf $2 \mathrm{ky} / ;$, Tesla; FLASH, Fast Long Angle Shot; TSE, Turbo Spin Echo; MT, Magnetization Transfer; YA, Younger Adults, OA, Older Adults; YA-OA, lifespan sample including younger, middle-aged and older adults

\section{Evaluation of previously published locus coeruleus masks}

Once a high-agreement volume of interest ( $\left.L C_{\text {metaMask }}\right)$ was established, published locus coeruleus masks were compared regarding their specificity and sensitivity. That is, we evaluated (1) how many voxels of a given mask fell within the $L C_{\text {metaMask }}$ relative to the total number of voxels in that mask and (2) how many voxels of the $L C_{\text {metaMask }}$ were included in each mask (relative to the total number of voxels in the $L C_{\text {metaMask). The mean of the quality }}$ metrics (specificity, sensitivity) was taken as indicator for the accuracy of a mask.

\section{Application of locus coeruleus meta mask to an independent clinical sample} Study design and participants

To determine whether the $L C_{\text {metaMask }}$ can detect clinically significant differences in LC integrity, eighteen participants with or known to be at-risk for mutations in genes associated 
medRxiv preprint doi: https://doi.org/10.1101/2020.11.16.20232561; this version posted February $2,2021$. The copyright holder for this preprint (which was not certified by peer review) is the author/funder, who has granted medRxiv a license to display the preprint in It is made available under a CC-BY-NC-ND 4.0 International license . LOWER LOCUS COERULEUS INTEGRITY IN ALZHEIMER'S

with ADAD (PSEN1 or APP) were investigated $(34.7 \pm 10.1$ years [mean \pm standard

531 deviation]; 9 9 ; see Table 2; data collection was interrupted by the COVID-19 pandemic).

532 Participants' consent was obtained according to the Declaration of Helsinki. The study was

533 approved by the ethical committee of the University of Southern California. Data were

534 acquired as part of a study employing the Human Connectome Protocol (HCP) in genetic

535 subtypes of AD (NIH U01AG051218, PI: Ringman; see adrc.usc.edu/scientists-researchers/

536 for more details). Genotyping confirmed mutations in seven of the eighteen participants (the

537 A431E substitution in PSEN1, $\mathrm{n}=6$; and the V717I substitution in $A P P, \mathrm{n}=1$; Goate et al.,

538 1991; Murrell et al., 2006; Yescas et al., 2006), of which four were symptomatic (see Table 2).

539 Participants underwent 3 T MRI, flortaucipir PET, and cognitive testing. LC MR-intensity, a

540 non-invasive proxy for neuronal density (Keren et al., 2015), was semi-automatically

541 extracted from high-resolution brainstem scans (Dahl et al., 2019). LC ratios - that is, a ratio

542 of peak LC intensity standardized to a pontine reference (Betts, Kirilina, et al., 2019; Liu et

543 al., 2017) — were computed across the rostrocaudal extent of the nucleus. Standard uptake

544 value ratios (SUVR) were calculated from partial volume corrected flortaucipir PET data

545 using cerebellar gray matter as the reference based on the PETSurfer tool from FreeSurfer

546 (Greve et al., 2014). SUVR images were mapped to the cortical surface which was parcellated

547 into 36 regions of interest (Desikan et al., 2006). Univariate associations between LC ratios,

548 clinical variables, cognitive status, and tau burden were evaluated using non-parametric

549 Wilcoxon rank sum tests and bootstrapped Spearman's correlations. The multivariate pattern

550 between LC ratios, cortical tau burden and cognitive decline was evaluated using a partial

551 least squares correlation (see below; Krishnan, Williams, McIntosh, \& Abdi, 2011; McIntosh

$552 \&$ Lobaugh, 2004). Two-tailed statistical tests were used with an alpha level of $p<0.05$. The

553 applied statistical tests did not include covariates. Participants with missing data were

554 excluded from the respective analyses (see below). We did not conduct a formal power

555 calculation, given that there was no available prior evidence on the studied phenomena. 
medRxiv preprint doi: https://doi.org/10.1101/2020.11.16.20232561; this version posted February $2,2021$. The copyright holder for this preprint (which was not certified by peer review) is the author/funder, who has granted medRxiv a license to display the preprint in It is made available under a CC-BY-NC-ND 4.0 International license

Table 2: Descriptive statistics for imaging subgroups

\begin{tabular}{lrrr}
\hline & ADAD-control & ADAD-presymptomatic & ADAD-symptomatic \\
\hline $\mathrm{n}$ & 11 & 3 & 4 \\
Mutation & $0 / 11$ & $3 / 3$ & $4 / 4$ \\
Mutation type & & PSENI (A431E; 3/3) & PSENI (A431E; 3/4) \\
Diagnosis & $0 / 11$ & $0 / 3$ & APP (V717I; $1 / 4)$ \\
CASI & 95.1 & 92.7 & $4 / 4$ \\
(std, range) & $(2.05 ; 92-97.7)$ & $(3.785 ; 90-97)$ & 74.9 \\
Age & 33.1 & 29 & $(11.844 ; 62.8-86.8)$ \\
(std, range) & $(11.0 ; 19-58)$ & $(6.1 ; 22-33)$ & 43.5 \\
Gender & 6 male & 0 male & $(1.3 ; 42-45)$ \\
& 5 female & 3 female & 3 male \\
\hline
\end{tabular}

Note: ADAD, autosomal-dominant Alzheimer's disease; ADAD-control: control participants not carrying the mutation, but genetically related to mutation carriers; ADAD-presymptomatic: presymptomatic mutation carriers (Washington University Clinical Dementia Rating Scale [CDR] scores of 0); ADAD-symptomatic: symptomatic mutation carriers; std. standard deviation; CASI, Cognitive Abilities Screening Instrument (Teng et al., 1994); PSEN1: Presenilin-1 protein (gene); APP: Amyloid- $\beta$ Precursor Protein (gene)

\section{Assessment of imaging data}

Structural MRI data were collected employing a 3 T Siemens Prisma scanner with a

32-channel head coil following a Human Connectome Project imaging approach (HCP; cf.

567 humanconnectome.org/). Only those sequences used in the current analyses are described

568 below.

A three-dimensional (3D) T1-weighted magnetization prepared gradient-echo

570 (MPRAGE) sequence with a duration of 6:38 min and the following parameters was applied:

571 repetition time $(\mathrm{TR})=2400 \mathrm{~ms}$; echo time $(\mathrm{TE})=2.22 \mathrm{~ms}$; inversion time $(\mathrm{TI})=1000 \mathrm{~ms}$;

572 flip angle $=8^{\circ}$; bandwidth $=220 \mathrm{~Hz} / \mathrm{Px}$; dimensions $=208 \times 300 \times 320$; isometric voxel size

$573=0.8 \mathrm{~mm}^{3}$. Based on this whole-brain (MPRAGE) sequence, a high-resolution, two-

574 dimensional (2D) T1-weighted TSE sequence was aligned perpendicularly to the plane of the

575 brainstem. Acquisition of the TSE sequence took 1:53 min, and the following parameters

576 were used: $\mathrm{TR}=750 \mathrm{~ms}$; $\mathrm{TE}=10 \mathrm{~ms}$; flip angle $=120^{\circ}$; bandwidth $=285 \mathrm{~Hz} / \mathrm{Px}$; dimensions

$577=512 \times 512 \times 11$; anisometric voxel size $=0.43 \times 0.43 \times 3.5 \mathrm{~mm}^{3}$ (mimicking the elongated

578 shape of the locus coeruleus). Each TSE scan consisted of eleven axial slices. 
medRxiv preprint doi: https://doi.org/10.1101/2020.11.16.20232561; this version posted February 2, 2021. The copyright holder for this preprint (which was not certified by peer review) is the author/funder, who has granted medRxiv a license to display the preprint in It is made available under a CC-BY-NC-ND 4.0 International license .

LOWER LOCUS COERULEUS INTEGRITY IN ALZHEIMER'S

PET data were collected using a 3 T Siemens Prisma scanner within the period of $90_{-}$ 120 min after the injection of the compound 18F-AV-1451 (total dose: $344 \mathrm{MBq}$ ). Low dose computerized tomography (CT) scans were acquired prior to the PET scans for attenuation correction. The dynamic PET scans included six frames of five-minute duration, with the

583 dimensions of $168 \times 168 \times 56$ and a voxel size of $1.5 \times 1.5 \times 4 \mathrm{~mm}^{3}$. The six dynamic scans 584 were rigidly aligned to the first one and averaged to create a static image for SUVR-based 585 analysis.

\section{Semi-automatic locus coeruleus intensity assessment using meta mask}

Leveraging the generated $L C_{\text {metaMask }}$ (see above), locus coeruleus intensity was semiautomatically extracted using a previously validated pipeline (Dahl et al., 2019; also see Ye et al., 2021 for a comparable approach). In short, individual whole brain and brainstem scans were iteratively aligned across participants using a template-based procedure implemented in Advanced Normalization Tools (version 2.1; ANTs; Avants et al., 2011; Avants, Tustison, \& 593 Song, 2009), and subsequently transformed to standard space (MNI-ICBM 152 linear, 0.5 594 mm; see Dahl et al., 2019 for a step-by-step description of the standardization). In standard 595 space, individual brainstem scans were masked using the high-confidence $L C_{\text {metaMask }}$ to remove non-LC tissue (using SPM12 in Matlab). To allow inter-subject comparisons of LC

597 data, a normalization of the arbitrarily scaled MR-intensity values is required (Betts, Kirilina, 598 et al., 2019). Thus, brainstem scans were additionally masked using a reference volume of 599 interest positioned in the central pontine white matter, as previously suggested (Ye et al., 6002021 ; dimensions: $4 \times 4 \mathrm{~mm}$ in plane, following the $L C_{\text {metaMask }}$ with a constant distance of 8.5 $601 \mathrm{~mm}$ [y-dimension] along the rostrocaudal axis; see Figure 3). Within the masked brainstem 602 scans, we then fully automatically searched for voxels of brightest intensity in the LC and 603 reference regions. Next, individual, spatially-resolved LC intensity ratios were computed for 604 each slice using the following formula (Dahl et al., 2019; Liu et al., 2017): 
medRxiv preprint doi: https://doi.org/10.1101/2020.11.16.20232561; this version posted February 2, 2021. The copyright holder for this preprint (which was not certified by peer review) is the author/funder, who has granted medRxiv a license to display the preprint in It is made available under a CC-BY-NC-ND 4.0 International license

$$
L C_{\text {Ratio }}=\frac{\max (L C)-\max (R e f)}{\max (\text { Ref })}
$$

Where $\max (L C)$ denotes the peak intensity for a given slice in the LC volume of interest and $\max ($ Ref $)$ indicates the peak intensity in the reference region. After extraction, ratios of the left and right hemisphere were averaged for further analyses to obtain more stable intensity estimates. Finally, the peak ratio across the rostrocaudal LC extent was calculated as proxy for overall locus coeruleus integrity.

\section{Assessment of cortical tau burden}

To evaluate the association of MR-indexed LC integrity to hallmarks of AD, we

calculated cortical tau burden from flortaucipir PET data.

First, each participant's whole brain MR data (MPRAGE) was preprocessed using a

617 reconstructed and parcellated into thirty-six anatomical regions of interest using Freesurfer 6186.0 (Dale, Fischl, \& Sereno, 1999; Desikan et al., 2006). Flortaucipir PET images were then co-registered within participants to whole brain (MPRAGE) native space. The Muller-Gartner (MG) method was used for partial volume correction of the PET data, as implemented in

621 PETSurfer (Greve et al., 2016). Standard uptake value ratios (SUVR) were calculated using 622 cerebellar gray matter as reference region. Finally, partial-volume corrected SUVR images 623 were mapped to the cortical surface and parcellated into thirty-six regions of interest (Desikan 624 et al., 2006). For further analyses, each region's SUVR data were averaged across

625 hemispheres to obtain more stable estimates of cortical tau burden. Tau PET data were not 626 available for two subjects. 
medRxiv preprint doi: https://doi.org/10.1101/2020.11.16.20232561; this version posted February 2, 2021. The copyright holder for this preprint (which was not certified by peer review) is the author/funder, who has granted medRxiv a license to display the preprint in It is made available under a CC-BY-NC-ND 4.0 International license .

LOWER LOCUS COERULEUS INTEGRITY IN ALZHEIMER'S

\section{Association of locus coeruleus intensity and cortical tau burden}

We employed a multivariate statistical approach to assess the relation between MR-

630 indexed locus coeruleus integrity and tau pathology across the cortex. Specifically, using a

631 Partial Least Squares Correlation (PLSC; Krishnan et al., 2011; McIntosh \& Lobaugh, 2004)

632 we estimated a latent tau pathology profile that is maximally related to LC integrity (cf.

633 Keresztes et al., 2017; Muehlroth et al., 2020).

First, a between-person Pearson's correlation matrix $(R)$ was computed between the

overall LC ratios (i.e., a vector $Y_{L C}$ with $n_{\text {Participants }} \times 1$ [overall intensity ratios]) and the tau

SUVR data (i.e., a matrix $X_{\text {Tau }}$ with $n_{\text {Participants }} \times 36$ [regions of interest]). This correlation

matrix $\left(R_{L C, T a u}=Y_{L C}{ }^{\mathrm{T}} X_{T a u}\right)$ was then decomposed into three matrices using a singular value

decomposition $\left(\operatorname{SVD} ; \operatorname{SVD}\left(R_{L C, T a u}\right)=U S V^{\mathrm{T}}\right)$. Whereby $U$ refers to a left singular vector of $\mathrm{LC}$

weights, $V^{\mathrm{T}}$ denotes a right singular matrix of regional tau weights, and $S$ is a diagonal matrix

of singular values. Based on this matrix decomposition, a single latent variable was extracted.

641 The latent variable optimally expresses (in a least squares sense) the pattern of interindividual

642 differences in regional tau burden that shares the largest amount of variance with

643 interindividual differences in overall LC intensity ratios. The statistical strength of the

644 extracted pattern (i.e., the latent variable) was evaluated using a permutation test (by

randomly re-ordering the observations in $X_{\text {Tau }}$ while leaving $Y_{L C}$ unchanged and re-calculating

the SVD; $\left.n_{\text {Permutations }}=10,000\right)$. Subsequently, the reliability of the contribution (i.e., weights

determined using a bootstrapping procedure $\left(n_{\text {Bootraps }}=10,000\right)$. A ratio of the region-specific

weights $\left(V^{\mathrm{T}}\right)$ and their corresponding bootstrapped standard errors provided bootstrap ratios 
medRxiv preprint doi: https://doi.org/10.1101/2020.11.16.20232561; this version posted February 2, 2021. The copyright holder for this preprint (which was not certified by peer review) is the author/funder, who has granted medRxiv a license to display the preprint in It is made available under a CC-BY-NC-ND 4.0 International license .

LOWER LOCUS COERULEUS INTEGRITY IN ALZHEIMER'S

\section{Cognitive assessments}

memory and attention. The cognitive assessment included screening instruments (the

658 Screening Instrument [CASI; Teng et al., 1994], and the Washington University Clinical

659 Dementia Rating Scale [CDR; measure: sum of boxes; cf. O’Bryant et al., 2008]). In addition, attention (Digit-Symbol-Substitution Test [DSST; Wechsler, 1981]; Digit Span [measure: normative data. Trail making data were not available for one subject. and cognitive performance, using the same methods as described above.

\section{Neuropathological assessment}

To characterize the pathology underlying the LC signal on MRI in ADAD, we 
medRxiv preprint doi: https://doi.org/10.1101/2020.11.16.20232561; this version posted February 2, 2021. The copyright holder for this preprint (which was not certified by peer review) is the author/funder, who has granted medRxiv a license to display the preprint in It is made available under a CC-BY-NC-ND 4.0 International license .

LOWER LOCUS COERULEUS INTEGRITY IN ALZHEIMER'S

680 for amyloid- $\beta$, and anti-alpha synuclein antibodies for Lewy Body pathology. Qualitative comparisons were made between patients and controls.

682

683

684

685

686

687

688

689

690

691

692

693

694

695

696

697

698

699

\section{Histopathology methods}

After 1-month fixation, tissue areas were dissected and paraffin-embedded and serially sectioned into $5 \mu \mathrm{m}$-thick sections using a microtome (Microm International Waldorf, Germany). Brain sections were counterstained with $\mathrm{H} \& \mathrm{E}$ and reagents were purchased from Sigma-Aldrich (St. Louis, MO, USA). Sections adjacent to H\&E were immunostained using the Leica Bond $\mathrm{RXm}^{\mathrm{TM}}$ automated staining processor (Leica Biosystems, Buffalo Grove, IL, USA). Tissue sections were stained using the Bond Polymer Refine AFP (Red) Detection System for all Abs except GFAP Ab and NeuN Ab which used Bond Polymer Refine DAB Detection System (Leica Biosystems). Antigen retrieval was performed with Epitope Retrieval Solution 1 (ER1, pH 6) for 20 min except for GFAP Ab which was for 10 min. Sections were then incubated with amyloid-beta (4G8, BioLegend, SIG \#800701, 1:4000) for 30 min, TAR DNA binding protein (TDP-43, Sigma, T11705; 1:1250) for 15 min, phosphortau (AT8, MN1020, Thermo Scientific, USA; 1:1000 for 15 min; GFAP Rb pAb, Chemicon, Temecula AB5804, CA, USA; 1;2500) for 15 min; (NeuN, AbCAM, ab104224, USA; 1:800) for 30m. a-Synuclein Rb pAb, Chemicon, AB5038, 1:2000 for 15 min.

Staining with 4-repeat isoform tau (RD4, Cosmo Bio Co. LTD. Inspiration of Life Science, Cat\# TIP-4RT-P01; 1:3000) and 3-repeat isoform tau (RD3, 05-803, Millipore, USA; 1:5000) required manual pretreatment outside autostainer. Sections heated in a pressure cooker at $125^{\circ}$ in citrate buffer $(\mathrm{CC} 2, \mathrm{pH} 6)$ for 90 min and treated with $88 \%$ Formic Acid for 10 min. Sections were then loaded in autostainer with Bond Polymer Refine Red Detection System for 15 min. Images were obtained with a Nikon Eclipse E400 brightfield microscope (Nikon Instruments Inc, Melville, NY, USA). All stains were performed at Children's Hospital of Los Angeles. 
medRxiv preprint doi: https://doi.org/10.1101/2020.11.16.20232561; this version posted February 2, 2021. The copyright holder for this preprint (which was not certified by peer review) is the author/funder, who has granted medRxiv a license to display the preprint in It is made available under a CC-BY-NC-ND 4.0 International license.

LOWER LOCUS COERULEUS INTEGRITY IN ALZHEIMER'S

707 Data availability

708 The here described LC meta mask as well as pontine reference mask is available for

709 download on an Open Science Framework repository (osf.io/sf2ky/). All sources for

710 previously published masks are listed in Table 1. For access to raw imaging and clinical data,

711 please refer to the HCP (https://nda.nih.gov/ccf).

712 
medRxiv preprint doi: https://doi.org/10.1101/2020.11.16.20232561; this version posted February 2, 2021. The copyright holder for this preprint (which was not certified by peer review) is the author/funder, who has granted medRxiv a license to display the preprint in perpetuity.

It is made available under a CC-BY-NC-ND 4.0 International license .

LOWER LOCUS COERULEUS INTEGRITY IN ALZHEIMER'S

\section{Acknowledgements}

714 The authors thank all study participants for their contribution.

715

716

\section{Competing interests}

717 The authors declare no competing financial interests.

718

\section{$719 \quad$ Funding}

MJD is recipient of a stipend from the GA. Lienert-Foundation and was supported by a stipend from the Davis School of Gerontology, University of Southern California. MM's work was supported by National Institutes of Health (NIH) grant R01AG025340, an Alexander von Humboldt fellowship, and a Max Planck Sabbatical Award. MW-B received support from the German Research Foundation (DFG, WE 4269/5-1) and the Jacobs Foundation (Early Career Research Fellowship 2017-2019). BLK was supported by a NIH grant F32AG057162. YS was supported by NIH grants RF1AG064584 and RF1AG056573. SG, KH, and CCM were supported by P30AG066530, JMR was supported by NIH grants U01AG051218, R01AG062007, and P30AG066530. The funders had no role in study design, data collection and analysis, decision to publish, or preparation of the 
medRxiv preprint doi: https://doi.org/10.1101/2020.11.16.20232561; this version posted February $2,2021$. The copyright holder for this preprint (which was not certified by peer review) is the author/funder, who has granted medRxiv a license to display the preprint in It is made available under a CC-BY-NC-ND 4.0 International license .

LOWER LOCUS COERULEUS INTEGRITY IN ALZHEIMER'S

References

731 Albert, M. S., Moss, M. B., Tanzi, R., \& Jones, K. (2001). Preclinical prediction of AD using neuropsychological tests. Journal of the International Neuropsychological Society, 7(5), 631-639. https://doi.org/10.1017/S1355617701755105

Alzheimer's Disease International. (2019). World Alzheimer Report 2019: Attitudes to Dementia. Alzheimer's Disease International: London.

Arendt, T., Brückner, M. K., Morawski, M., Jäger, C., \& Gertz, H. J. (2015). Early neurone loss in Alzheimer's disease: cortical or subcortical? Acta Neuropathologica Communications, 3, 10. https://doi.org/10.1186/s40478-015-0187-1

Astafiev, S. V., Snyder, A. Z., Shulman, G. L., \& Corbetta, M. (2010). Comment on "Modafinil shifts human locus coeruleus to low-tonic, high-phasic activity during functional MRI" and "Homeostatic sleep pressure and responses to sustained attention in the suprachiasmatic area." Science, 328(5976), 309.

Avants, B. B., Tustison, N. J., Song, G., Cook, P. A., Klein, A., \& Gee, J. C. (2011). A reproducible evaluation of ANTs similarity metric performance in brain image registration. NeuroImage, 54(3), 2033-2044. https://doi.org/10.1016/j.neuroimage.2010.09.025

Avants, B. B., Tustison, N., \& Song, G. (2009). Advanced Normalization Tools: V1.0. Insight Journal, 2. https://doi.org/http://hdl.handle.net/10380/3113

Bateman, R. J., Aisen, P. S., De Strooper, B., Fox, N. C., Lemere, C. A., Ringman, J. M., ... Xiong, C. (2011, January 6). Autosomal-dominant Alzheimer's disease: A review and proposal for the prevention of Alzheimer's disease. Alzheimer's Research and Therapy. BioMed Central. https://doi.org/10.1186/alzrt59

Bateman, R. J., Xiong, C., Benzinger, T. L. S., Fagan, A. M., Goate, A., Fox, N. C., ... Morris, J. C. (2012). Clinical and biomarker changes in dominantly inherited Alzheimer's 
medRxiv preprint doi: https://doi.org/10.1101/2020.11.16.20232561; this version posted February $2,2021$. The copyright holder for this preprint (which was not certified by peer review) is the author/funder, who has granted medRxiv a license to display the preprint in It is made available under a CC-BY-NC-ND 4.0 International license .

LOWER LOCUS COERULEUS INTEGRITY IN ALZHEIMER'S

disease. New England Journal of Medicine, 367(9), 795-804. https://doi.org/10.1056/NEJMoa1202753

Belleville, S., Fouquet, C., Hudon, C., Zomahoun, H. T. V., \& Croteau, J. (2017). to Alzheimer's type dementia in older adults: A systematic review and meta-analysis. Neuropsychology Review, 27(4), 328-353. https://doi.org/10.1007/s11065-017-9361-5

762

Berridge, C. W., \& Waterhouse, B. D. (2003). The locus coeruleus-noradrenergic system: Modulation of behavioral state and state-dependent cognitive processes. Brain Research Reviews, 42(1), 33-84. https://doi.org/10.1016/S0165-0173(03)00143-7

Bertram, L., Lill, C. M., \& Tanzi, R. E. (2010, October 21). The genetics of alzheimer disease: Back to the future. Neuron. Neuron. https://doi.org/10.1016/j.neuron.2010.10.013

Betts, M. J., Cardenas-Blanco, A., Kanowski, M., Jessen, F., \& Düzel, E. (2017). In vivo MRI assessment of the human locus coeruleus along its rostrocaudal extent in young and older adults. NeuroImage, 163, 150-159. https://doi.org/10.1016/j.neuroimage.2017.09.042

Betts, M. J., Cardenas-Blanco, A., Kanowski, M., Spottke, A., Teipel, S. J., Kilimann, I., ... Düzel, E. (2019). Locus coeruleus MRI contrast is reduced in Alzheimer's disease dementia and correlates with CSF A $\beta$ levels. Alzheimer's \& Dementia: Diagnosis, Assessment \& Disease Monitoring, 11, 281-285. https://doi.org/10.1016/j.dadm.2019.02.001

Betts, M. J., Kirilina, E., Otaduy, M. C. G., Ivanov, D., Acosta-Cabronero, J., Callaghan, M. F., ... Hämmerer, D. (2019). Locus coeruleus imaging as a biomarker for noradrenergic dysfunction in neurodegenerative diseases. Brain, 142(9), 2558-2571. https://doi.org/10.1093/brain/awz193

Bouret, S., \& Sara, S. J. (2005). Network reset: A simplified overarching theory of locus coeruleus noradrenaline function. Trends in Neurosciences, 28(11), 574-582. https://doi.org/10.1016/j.tins.2005.09.002 
medRxiv preprint doi: https://doi.org/10.1101/2020.11.16.20232561; this version posted February $2,2021$. The copyright holder for this preprint (which was not certified by peer review) is the author/funder, who has granted medRxiv a license to display the preprint in It is made available under a CC-BY-NC-ND 4.0 International license

LOWER LOCUS COERULEUS INTEGRITY IN ALZHEIMER'S

782 Braak, H., Thal, D. R., Ghebremedhin, E., \& Del Tredici, K. (2011). Stages of the pathologic process in Alzheimer disease: Age categories from 1 to 100 years. Journal of Neuropathology and Experimental Neurology, 70(11), 960-969. https://doi.org/10.1097/NEN.0b013e318232a379

Campion, D., Dumanchin, C., Hannequin, D., Dubois, B., Belliard, S., Puel, M., ... Frebourg, T. (1999). Early-onset autosomal dominant Alzheimer disease: Prevalence, genetic heterogeneity, and mutation spectrum. American Journal of Human Genetics, 65(3), 664-670. https://doi.org/10.1086/302553

Canter, R. G., Penney, J., \& Tsai, L. H. (2016, November 9). The road to restoring neural circuits for the treatment of Alzheimer's disease. Nature. Nature Publishing Group. https://doi.org/10.1038/nature20412

Cassidy, C. M., Zucca, F. A., Girgis, R. R., Baker, S. C., Weinstein, J. J., Sharp, M. E., ... Horga, G. (2019). Neuromelanin-sensitive MRI as a noninvasive proxy measure of dopamine function in the human brain. Proceedings of the National Academy of Sciences

Chalermpalanupap, T., Schroeder, J. P., Rorabaugh, J. M., Liles, L. C., Lah, J. J., Levey, A. I., of the United States of America, 116(11), 5108-5117. \& Weinshenker, D. (2018). Locus coeruleus ablation exacerbates cognitive deficits, neuropathology, and lethality in P301S tau transgenic mice. The Journal of Neuroscience : The Official Journal of the Society for Neuroscience, 38(1), 74-92. https://doi.org/10.1523/JNEUROSCI.1483-17.2017 consequences of pretangle tau in the locus coeruleus. Neural Plasticity, 2017, 7829507. https://doi.org/10.1155/2017/7829507

Corbetta, M., Patel, G., \& Shulman, G. L. (2008). The reorienting system of the human brain: From environment to theory of mind. Neuron, 58(3), 306-324. 
medRxiv preprint doi: https://doi.org/10.1101/2020.11.16.20232561; this version posted February $2,2021$. The copyright holder for this preprint (which was not certified by peer review) is the author/funder, who has granted medRxiv a license to display the preprint in It is made available under a CC-BY-NC-ND 4.0 International license

LOWER LOCUS COERULEUS INTEGRITY IN ALZHEIMER'S

https://doi.org/10.1016/j.neuron.2008.04.017

Craft, S., Newcomer, J., Kanne, S., Dagogo-Jack, S., Cryer, P., Sheline, Y., ... Alderson, A. 4580(95)02002-0

Crary, J. F., Trojanowski, J. Q., Schneider, J. A., Abisambra, J. F., Abner, E. L., Alafuzoff, I., ... Nelson, P. T. (2014). Primary age-related tauopathy (PART): a common pathology associated with human aging. Acta Neuropathologica, 128(6), 755-766. https://doi.org/10.1007/s00401-014-1349-0

Dahl, M. J., Mather, M., Düzel, S., Bodammer, N. C., Lindenberger, U., Kühn, S., \& WerkleBergner, M. (2019). Rostral locus coeruleus integrity is associated with better memory performance in older adults. Nature Human Behaviour, 3(11), 1203-1214.

Dahl, M. J., Mather, M., Sander, M. C., \& Werkle-Bergner, M. (2020). Noradrenergic responsiveness supports selective attention across the adult lifespan. Journal of Neuroscience, 40(22), 4372-4390. https://doi.org/10.1523/JNEUROSCI.0398-19.2020

Dale, A. M., Fischl, B., \& Sereno, M. I. (1999). Cortical surface-based analysis: I.

Desikan, R. S., Ségonne, F., Fischl, B., Quinn, B. T., Dickerson, B. C., Blacker, D., ... Killiany, R. J. (2006). An automated labeling system for subdividing the human cerebral cortex on MRI scans into gyral based regions of interest. NeuroImage, 31(3), 968-980. https://doi.org/10.1016/j.neuroimage.2006.01.021

831 Dordevic, M., Müller-Fotti, A., Müller, P., Schmicker, M., Kaufmann, J., \& Müller, N. G. 
medRxiv preprint doi: https://doi.org/10.1101/2020.11.16.20232561; this version posted February $2,2021$. The copyright holder for this preprint (which was not certified by peer review) is the author/funder, who has granted medRxiv a license to display the preprint in It is made available under a CC-BY-NC-ND 4.0 International license .

LOWER LOCUS COERULEUS INTEGRITY IN ALZHEIMER'S

Reports, 1(1), 159-167. https://doi.org/10.3233/adr-170021

835

836

Duszkiewicz, A. J., McNamara, C. G., Takeuchi, T., \& Genzel, L. (2019). Novelty and Dopaminergic Modulation of Memory Persistence: A Tale of Two Systems. Trends in Neurosciences, 42(2), 102-114. https://doi.org/10.1016/J.TINS.2018.10.002

Ehrenberg, A. J., Nguy, A. K., Theofilas, P., Dunlop, S., Suemoto, C. K., Di Lorenzo Alho, A. T., ... Grinberg, L. T. (2017). Quantifying the accretion of hyperphosphorylated tau in the locus coeruleus and dorsal raphe nucleus: The pathological building blocks of early Alzheimer's disease. Neuropathology and Applied Neurobiology, 43(5), 393-408. https://doi.org/10.1111/nan.12387

Elman, J. A., Puckett, O. K., Beck, A., Panizzon, M. S., Sanderson-Cimino, M. E., Gustavson, D. E., ... Kremen, W. S. (2020). MRI-assessed locus coeruleus integrity is heritable and associated with cognition, Alzheimer's risk, and sleep-wake disturbance. Alzheimer's \& Dementia, 16(S5). https://doi.org/10.1002/alz.044862

Fernandes, P., Regala, J., Correia, F., \& Gonçalves-Ferreira, A. J. (2012). The human locus coeruleus 3-D stereotactic anatomy. Surgical and Radiologic Anatomy, 34(10), 879-885. https://doi.org/10.1007/s00276-012-0979-y

Ghosh, A., Torraville, S. E., Mukherjee, B., Walling, S. G., Martin, G. M., Harley, C. W., \& Yuan, Q. (2019). An experimental model of Braak's pretangle proposal for the origin of Alzheimer's disease: The role of locus coeruleus in early symptom development. Alzheimer's Research and Therapy, 11(1), 59. https://doi.org/10.1186/s13195-019-05112

Goate, A., Chartier-Harlin, M. C., Mullan, M., Brown, J., Crawford, F., Fidani, L., ... Hardy, J. (1991). Segregation of a missense mutation in the amyloid precursor protein gene with familial Alzheimer's disease. Nature, 349(6311), 704-706. https://doi.org/10.1038/349704a0

González, H. M., Mungas, D., \& Haan, M. N. (2002). A verbal learning and memory test for 
medRxiv preprint doi: https://doi.org/10.1101/2020.11.16.20232561; this version posted February $2,2021$. The copyright holder for this preprint (which was not certified by peer review) is the author/funder, who has granted medRxiv a license to display the preprint in It is made available under a CC-BY-NC-ND 4.0 International license

LOWER LOCUS COERULEUS INTEGRITY IN ALZHEIMER'S

English- and Spanish-speaking older Mexican-American adults. Clinical Neuropsychologist, 16(4), 439-451. https://doi.org/10.1076/clin.16.4.439.13908

Greve, D. N., Salat, D. H., Bowen, S. L., Izquierdo-Garcia, D., Schultz, A. P., Catana, C., ... Johnson, K. A. (2016). Different partial volume correction methods lead to different conclusions: An 18F-FDG-PET study of aging. NeuroImage, 132, 334-343. https://doi.org/10.1016/j.neuroimage.2016.02.042

Greve, D. N., Svarer, C., Fisher, P. M., Feng, L., Hansen, A. E., Baare, W., ... Knudsen, G. M. (2014). Cortical surface-based analysis reduces bias and variance in kinetic modeling of brain PET data. NeuroImage, 92, 225-236. https://doi.org/10.1016/j.neuroimage.2013.12.021

Grinberg, L. T., \& Heinsen, H. (2017). Light at the beginning of the tunnel? Investigating early mechanistic changes in Alzheimer's disease. Brain, 140(11), 2770-2773. https://doi.org/10.1093/brain/awx261

Hämmerer, D., Callaghan, M. F., Hopkins, A., Kosciessa, J., Betts, M., Cardenas-Blanco, A., ... Düzel, E. (2018). Locus coeruleus integrity in old age is selectively related to memories linked with salient negative events. Proceedings of the National Academy of Sciences of the United States of America, 115, 2228-2233. https://doi.org/10.1073/pnas.1712268115

Hanseeuw, B. J., Betensky, R. A., Jacobs, H. I. L., Schultz, A. P., Sepulcre, J., Becker, J. A., ... Johnson, K. (2019). Association of amyloid and tau with cognition in preclinical Alzheimer disease. JAMA Neurology, Advance online publication. https://doi.org/10.1001/jamaneurol.2019.1424

Heneka, M. T., Nadrigny, F., Regen, T., Martinez-Hernandez, A., Dumitrescu-Ozimek, L., Terwel, D., ... Kummer, M. P. (2010). Locus ceruleus controls Alzheimer's disease pathology by modulating microglial functions through norepinephrine. Proceedings of the National Academy of Sciences of the United States of America, 107(13), 6058-6063. 
medRxiv preprint doi: https://doi.org/10.1101/2020.11.16.20232561; this version posted February $2,2021$. The copyright holder for this preprint (which was not certified by peer review) is the author/funder, who has granted medRxiv a license to display the preprint in It is made available under a CC-BY-NC-ND 4.0 International license

LOWER LOCUS COERULEUS INTEGRITY IN ALZHEIMER'S

https://doi.org/10.1073/pnas.0909586107

Jacobs, H. I. L., Becker, A., Sperling, R. A., Guzman-Velez, E., Baena, A., Uquillas, F. d'Oleire, ... Quiroz, Y. T. (2019). P2-425: Locus coeruleus intensity is associated with early amyloid and tau pathology in preclinical autosomal dominant Alzheimer's disease. Alzheimer's \& Dementia, 15, P774-P775. https://doi.org/10.1016/j.jalz.2019.06.2832

Jacobs, H. I. L., Riphagen, J. M., Ramakers, I. H. G. B., \& Verhey, F. R. J. (2019). memory, and neuropsychiatric symptoms. Molecular Psychiatry, Advance online publication. https://doi.org/10.1038/s41380-019-0437-x

Jagust, W. (2018). Imaging the evolution and pathophysiology of Alzheimer disease. Nature Reviews Neuroscience, 19, 687-700. https://doi.org/10.1038/s41583-018-0067-3

Janssen, J. C., Hall, M., Fox, N. C., Harvey, R. J., Beck, J., Dickinson, A., ... Rossor, M. N. (2000). Alzheimer's disease due to an intronic presenilin-1 (PSEN1 intron 4) mutation. A clinicopathological study. Brain, 123(5), 894-907. https://doi.org/10.1093/brain/123.5.894

Jessen, F., Spottke, A., Boecker, H., Brosseron, F., Buerger, K., Catak, C., ... Düzel, E. (2018). Design and first baseline data of the DZNE multicenter observational study on predementia Alzheimer's disease (DELCODE). Alzheimer's Research \& Therapy, 10, 15. https://doi.org/10.1186/s13195-017-0314-2

Kelly, S. C., He, B., Perez, S. E., Ginsberg, S. D., Mufson, E. J., \& Counts, S. E. (2017). Locus coeruleus cellular and molecular pathology during the progression of Alzheimer's disease. Acta Neuropathologica Communications, 5(1), 8. https://doi.org/10.1186/s40478-017-0411-2 mapping of the human locus coeruleus. NeuroImage, 47(4), 1261-1267. https://doi.org/10.1016/j.neuroimage.2009.06.012 
medRxiv preprint doi: https://doi.org/10.1101/2020.11.16.20232561; this version posted February $2,2021$. The copyright holder for this preprint (which was not certified by peer review) is the author/funder, who has granted medRxiv a license to display the preprint in It is made available under a CC-BY-NC-ND 4.0 International license

LOWER LOCUS COERULEUS INTEGRITY IN ALZHEIMER'S

912 Keren, N. I., Taheri, S., Vazey, E. M., Morgan, P. S., Granholm, A. C. E., Aston-Jones, G., \&

913

914

915

916

917

918

919

920

921

922

923

924

925

926

927

928

929

930

931

932

933

934

935

936

937

Eckert, M. A. (2015). Histologic validation of locus coeruleus MRI contrast in postmortem tissue. NeuroImage, 113, 235-245.

https://doi.org/10.1016/j.neuroimage.2015.03.020

Keresztes, A., Bender, A. R., Bodammer, N. C., Lindenberger, U., Shing, Y. L., \& WerkleBergner, M. (2017). Hippocampal maturity promotes memory distinctiveness in childhood and adolescence. Proceedings of the National Academy of Sciences of the United States of America, 114(34), 9212-9217. https://doi.org/10.1073/pnas.1710654114

Klein, A., Andersson, J., Ardekani, B. A., Ashburner, J., Avants, B., Chiang, M.-C., ... Parsey, R. V. (2009). Evaluation of 14 nonlinear deformation algorithms applied to human brain MRI registration. NeuroImage, 46(3), 786-802.

https://doi.org/10.1016/J.NEUROIMAGE.2008.12.037

Krishnan, A., Williams, L. J., McIntosh, A. R., \& Abdi, H. (2011). Partial Least Squares (PLS) methods for neuroimaging: A tutorial and review. NeuroImage, 56(2), 455-475. https://doi.org/10.1016/j.neuroimage.2010.07.034

La Joie, R., Visani, A. V., Baker, S. L., Brown, J. A., Bourakova, V., Cha, J., ... Rabinovici, G. D. (2020). Prospective longitudinal atrophy in Alzheimer's disease correlates with the intensity and topography of baseline tau-PET. Science Translational Medicine, 12(524), eaau5732. https://doi.org/10.1126/scitranslmed.aau5732

Lee, T.-H., Greening, S. G., Ueno, T., Clewett, D., Ponzio, A., Sakaki, M., \& Mather, M. (2018). Arousal increases neural gain via the locus coeruleus-noradrenaline system in younger adults but not in older adults. Nature Human Behaviour, 2(5), 356-366. https://doi.org/10.1038/s41562-018-0344-1

Lindenberger, U., von Oertzen, T., Ghisletta, P., \& Hertzog, C. (2011). Cross-sectional age variance extraction: What's change got to do with it? Psychology and Aging, 26(1), 3447. https://doi.org/10.1037/a0020525 
medRxiv preprint doi: https://doi.org/10.1101/2020.11.16.20232561; this version posted February $2,2021$. The copyright holder for this preprint (which was not certified by peer review) is the author/funder, who has granted medRxiv a license to display the preprint in

Liu, K. Y., Acosta-Cabronero, J., Cardenas-Blanco, A., Loane, C., Berry, A. J., Betts, M. J., ... Hämmerer, D. (2019). In vivo visualization of age-related differences in the locus coeruleus. Neurobiology of Aging, 74, 101-111. https://doi.org/10.1016/j.neurobiolaging.2018.10.014

Liu, K. Y., Kievit, R. A., Tsvetanov, K. A., Betts, M. J., Düzel, E., Rowe, J. B., ... Hämmerer, D. (2020). Noradrenergic-dependent functions are associated with age-related locus coeruleus signal intensity differences. Nature Communications, 11(1), 1712. https://doi.org/10.1038/s41467-020-15410-w

Liu, K. Y., Marijatta, F., Hämmerer, D., Acosta-Cabronero, J., Düzel, E., \& Howard, R. J. (2017). Magnetic resonance imaging of the human locus coeruleus: A systematic review. Neuroscience and Biobehavioral Reviews, 83, 325-355. https://doi.org/10.1016/j.neubiorev.2017.10.023

Lyness, S. A., Zarow, C., \& Chui, H. C. (2003, January 1). Neuron loss in key cholinergic and aminergic nuclei in Alzheimer disease: A meta-analysis. Neurobiology of Aging. Elsevier. https://doi.org/10.1016/S0197-4580(02)00057-X

Mäki-Marttunen, V., \& Espeseth, T. (2020). Uncovering the locus coeruleus: comparison of localization methods for functional analysis. NeuroImage, 117409. https://doi.org/10.1016/j.neuroimage.2020.117409

Makropoulos, A., Robinson, E. C., Schuh, A., Wright, R., Fitzgibbon, S., Bozek, J., ... pipeline for neonatal cortical surface reconstruction. NeuroImage, 173, 88-112.

960 Marien, M. R., Colpaert, F. C., \& Rosenquist, A. C. (2004). Noradrenergic mechanisms in neurodegenerative diseases: A theory. Brain Research Reviews, 45(1), 38-78. https://doi.org/10.1016/j.brainresrev.2004.02.002

963 Mather, M., Clewett, D., Sakaki, M., \& Harley, C. W. (2016). Norepinephrine ignites local 
medRxiv preprint doi: https://doi.org/10.1101/2020.11.16.20232561; this version posted February $2,2021$. The copyright holder for this preprint (which was not certified by peer review) is the author/funder, who has granted medRxiv a license to display the preprint in It is made available under a CC-BY-NC-ND 4.0 International license .

LOWER LOCUS COERULEUS INTEGRITY IN ALZHEIMER'S

hotspots of neuronal excitation: How arousal amplifies selectivity in perception and memory. Behavioral and Brain Sciences, 39, e200. https://doi.org/10.1017/S0140525X15000667

Mather, M., \& Harley, C. W. (2016). The locus coeruleus: Essential for maintaining cognitive function and the aging brain. Trends in Cognitive Sciences, 20(3), 214-226. https://doi.org/10.1016/j.tics.2016.01.001

McIntosh, A. R., \& Lobaugh, N. J. (2004). Partial least squares analysis of neuroimaging data: Applications and advances. In NeuroImage (Vol. 23). Neuroimage. https://doi.org/10.1016/j.neuroimage.2004.07.020

Miyoshi, F., Ogawa, T., Kitao, S. I., Kitayama, M., Shinohara, Y., Takasugi, M., ... Kaminou, T. (2013). Evaluation of Parkinson disease and Alzheimer disease with the use of neuromelanin MR imaging and123I-metaiodobenzylguanidine scintigraphy. American Test scores can be predicted from whole brain MRI in Alzheimer's disease. NeuroImage: Clinical, 13, 415-427. https://doi.org/10.1016/j.nicl.2016.12.011

Muehlroth, B. E., Sander, M. C., Fandakova, Y., Grandy, T. H., Rasch, B., Lee Shing, Y., \& Werkle-Bergner, M. (2020). Memory quality modulates the effect of aging on memory consolidation during sleep: Reduced maintenance but intact gain. NeuroImage, 209. https://doi.org/10.1016/j.neuroimage.2019.116490

Murrell, J., Ghetti, B., Cochran, E., Macias-Islas, M. A., Medina, L., Varpetian, A., ... Ringman, J. M. (2006). The A431E mutation in PSEN1 causing Familial Alzheimer's Disease originating in Jalisco State, Mexico: An additional fifteen families. Neurogenetics, 7(4), 277-279. https://doi.org/10.1007/s10048-006-0053-1 the Substantia nigra and locus ceruleus at $1.5 \mathrm{~T}$ using a 3D-gradient echo sequence with 
medRxiv preprint doi: https://doi.org/10.1101/2020.11.16.20232561; this version posted February $2,2021$. The copyright holder for this preprint (which was not certified by peer review) is the author/funder, who has granted medRxiv a license to display the preprint in It is made available under a CC-BY-NC-ND 4.0 International license

LOWER LOCUS COERULEUS INTEGRITY IN ALZHEIMER'S

magnetization transfer contrast. Magnetic Resonance in Medical Sciences : MRMS : An Official Journal of Japan Society of Magnetic Resonance in Medicine, 7(4), 205-210. Retrieved from http://www.ncbi.nlm.nih.gov/pubmed/19110515

Nasreddine, Z. S., Phillips, N. A., Bédirian, V., Charbonneau, S., Whitehead, V., Collin, I., ... Chertkow, H. (2005). The Montreal Cognitive Assessment, MoCA: A brief screening tool for mild cognitive impairment. Journal of the American Geriatrics Society, 53(4), 695699. https://doi.org/10.1111/j.1532-5415.2005.53221.x

O’Bryant, S. E., Waring, S. C., Cullum, C. M., Hall, J., Lacritz, L., Massman, P. J., ... Doody,

O’Dell, T. J., Connor, S. A., Guglietta, R., \& Nguyen, P. V. (2015). $\beta$-Adrenergic receptor signaling and modulation of long-term potentiation in the mammalian hippocampus. Learning \& Memory, 22(9), 461-471. https://doi.org/10.1101/1m.031088.113

Parker, J., Mozaffar, T., Messmore, A., Deignan, J. L., Kimonis, V. E., \& Ringman, J. M. (2019). Homozygosity for the A431E mutation in PSEN1 presenting with a relatively aggressive phenotype. Neuroscience Letters, 699, 195-198. https://doi.org/10.1016/j.neulet.2019.01.047

Penny, W., Friston, K., Ashburner, J., Kiebel, S., \& Nichols, T. (2007). Statistical Parametric Mapping: The Analysis of Functional Brain Images. Statistical Parametric Mapping: The Analysis of Functional Brain Images. Elsevier Ltd. https://doi.org/10.1016/B978-012-372560-8.X5000-1

Poe, G. R., Foote, S., Eschenko, O., Johansen, J. P., Bouret, S., Aston-Jones, G., ... Sara, S. J. (2020). Locus coeruleus: a new look at the blue spot. Nature Reviews Neuroscience, 1-

1015 Possin, K. L., Laluz, V. R., Alcantar, O. Z., Miller, B. L., \& Kramer, J. H. (2011). Distinct 
medRxiv preprint doi: https://doi.org/10.1101/2020.11.16.20232561; this version posted February $2,2021$. The copyright holder for this preprint (which was not certified by peer review) is the author/funder, who has granted medRxiv a license to display the preprint in It is made available under a CC-BY-NC-ND 4.0 International license.

LOWER LOCUS COERULEUS INTEGRITY IN ALZHEIMER'S

1016

1017

1018

1019

1020

1021

1022

1023

1024

1025

1026

1027

1028

1029

1030

1031

1032

1033

1034

1035

1036

1037

1038

1039

1040

1041

neuroanatomical substrates and cognitive mechanisms of figure copy performance in Alzheimer's disease and behavioral variant frontotemporal dementia. Neuropsychologia, 49(1), 43-48. https://doi.org/10.1016/j.neuropsychologia.2010.10.026

Priovoulos, N., Jacobs, H. I. L., Ivanov, D., Uludag, K., Verhey, F. R. J., \& Poser, B. A. (2017). High-resolution in vivo imaging of human locus coeruleus by magnetization transfer MRI at 3T and 7T. NeuroImage, 168, 127-136.

https://doi.org/10.1016/j.neuroimage.2017.07.045

Ringman, J. M. (2005). What the study of persons at risk for familial Alzheimer's disease can tell us about the earliest stages of the disorder: A review. In Journal of Geriatric Psychiatry and Neurology (Vol. 18, pp. 228-233). Sage PublicationsSage CA: Thousand Oaks, CA. https://doi.org/10.1177/0891988705281878

Ringman, J. M., Monsell, S., Ng, D. W., Zhou, Y., Nguyen, A., Coppola, G., ... Vinters, H. V. (2016). Neuropathology of Autosomal Dominant Alzheimer Disease in the National Alzheimer Coordinating Center Database. Journal of Neuropathology \& Experimental Neurology, 75(3), 284-290. https://doi.org/10.1093/jnen/nlv028

Rohlfing, T., Brandt, R., Menzel, R., \& Maurer, C. R. (2004). Evaluation of atlas selection strategies for atlas-based image segmentation with application to confocal microscopy images of bee brains. NeuroImage, 21(4), 1428-1442.

https://doi.org/10.1016/j.neuroimage.2003.11.010

Rorabaugh, J. M., Chalermpalanupap, T., Botz-Zapp, C. A., Fu, V. M., Lembeck, N. A., Cohen, R. M., \& Weinshenker, D. (2017). Chemogenetic locus coeruleus activation restores reversal learning in a rat model of Alzheimer's disease. Brain, 140(11), 30233038. https://doi.org/10.1093/brain/awx232

Ryman, D. C., Acosta-Baena, N., Aisen, P. S., Bird, T., Danek, A., Fox, N. C., ... Bateman, R. J. (2014). Symptom onset in autosomal dominant Alzheimer disease: A systematic review and meta-analysis. Neurology, 83(3), 253-260. 
medRxiv preprint doi: https://doi.org/10.1101/2020.11.16.20232561; this version posted February $2,2021$. The copyright holder for this preprint (which was not certified by peer review) is the author/funder, who has granted medRxiv a license to display the preprint in It is made available under a CC-BY-NC-ND 4.0 International license .

LOWER LOCUS COERULEUS INTEGRITY IN ALZHEIMER'S

https://doi.org/10.1212/WNL.0000000000000596

1043

1044

1045

1046

1047

1048

1049

1050

1051

1052

1053

1054

1055

1056

1057

1058

1059

1060

1061

1062

1063

1064

1065

1066

1067

Sabuncu, M. R., Yeo, B. T. T., Van Leemput, K., Fischl, B., \& Golland, P. (2010). A

generative model for image segmentation based on label fusion. IEEE Transactions on Medical Imaging, 29(10), 1714-1729. https://doi.org/10.1109/TMI.2010.2050897

Sara, S. J. (2009). The locus coeruleus and noradrenergic modulation of cognition. Nature Reviews Neuroscience, 10(3), 211-223. https://doi.org/10.1038/nrn2573

Sasaki, M., Shibata, E., Tohyama, K., Takahashi, J., Otsuka, K., Tsuchiya, K., ... Sakai, A. (2006). Neuromelanin magnetic resonance imaging of locus ceruleus and substantia nigra in Parkinson's disease. NeuroReport, 17(11), 1215-1218. https://doi.org/10.1097/01.wnr.0000227984.84927.a7

Satoh, A., \& Iijima, K. M. (2019). Roles of tau pathology in the locus coeruleus (LC) in ageassociated pathophysiology and Alzheimer's disease pathogenesis: Potential strategies to protect the LC against aging. Brain Research, 1702, 17-28. https://doi.org/10.1016/J.BRAINRES.2017.12.027

Schoenberg, M. R., Dawson, K. A., Duff, K., Patton, D., Scott, J. G., \& Adams, R. L. (2006). Test performance and classification statistics for the Rey Auditory Verbal Learning Test in selected clinical samples. Archives of Clinical Neuropsychology, 21(7), 693-703. https://doi.org/10.1016/j.acn.2006.06.010

Snider, B. J., Norton, J., Coats, M. A., Chakraverty, S., Hou, C. E., Jervis, R., ... Morris, J. C. (2005). Novel presenilin 1 mutation (S170F) causing Alzheimer disease with lewy bodies in the third decade of life. Archives of Neurology, 62(12), 1821-1830. https://doi.org/10.1001/archneur.62.12.1821

Stratmann, K., Heinsen, H., Korf, H. W., Del Turco, D., Ghebremedhin, E., Seidel, K., ... Rüb, U. (2016). Precortical Phase of Alzheimer's Disease (AD)-Related Tau Cytoskeletal Pathology. Brain Pathology, 26(3), 371-386. https://doi.org/10.1111/bpa.12289

Sun, W., Tang, Y., Qiao, Y., Ge, X., Mather, M., Ringman, J. M., \& Shi, Y. (2020). A 
medRxiv preprint doi: https://doi.org/10.1101/2020.11.16.20232561; this version posted February $2,2021$. The copyright holder for this preprint (which was not certified by peer review) is the author/funder, who has granted medRxiv a license to display the preprint in It is made available under a CC-BY-NC-ND 4.0 International license

LOWER LOCUS COERULEUS INTEGRITY IN ALZHEIMER'S

1068

1069

1070

1071

1072

1073

1074

1075

1076

1077

1078

1079

1080

1081

1082

1083

1084

1085

1086

1087

1088

1089

1090

1091

1092

1093

probabilistic atlas of locus coeruleus pathways to transentorhinal cortex for connectome imaging in Alzheimer's disease. NeuroImage, 223, 117301.

https://doi.org/10.1016/j.neuroimage.2020.117301

Takahashi, J., Shibata, T., Sasaki, M., Kudo, M., Yanezawa, H., Obara, S., ... Terayama, Y. (2015). Detection of changes in the locus coeruleus in patients with mild cognitive impairment and Alzheimer's disease: High-resolution fast spin-echo T1-weighted imaging. Geriatrics and Gerontology International, 15(3), 334-340. https://doi.org/10.1111/ggi.12280

Takeuchi, T., Duszkiewicz, A. J., Sonneborn, A., Spooner, P. A., Yamasaki, M., Watanabe, M., ... Morris, R. G. M. (2016). Locus coeruleus and dopaminergic consolidation of everyday memory. Nature, 537(7620), 357-362. https://doi.org/10.1038/nature19325

Tanzi, R. E., \& Bertram, L. (2005, February 25). Twenty years of the Alzheimer's disease amyloid hypothesis: A genetic perspective. Cell. Cell Press.

https://doi.org/10.1016/j.cell.2005.02.008

Teng, E. L., Hasegawa, K., Homma, A., Imai, Y., Larson, E., Graves, A., ... White, L. R. (1994). The Cognitive Abilities Screening Instrument (CASI): A Practical Test for CrossCultural Epidemiological Studies of Dementia. International Psychogeriatrics, 6(1), 4558. https://doi.org/10.1017/s1041610294001602

Theofilas, P., Dunlop, S., Heinsen, H., \& Grinberg, L. T. (2015). Turning on the light within: Subcortical nuclei of the isodentritic core and their role in Alzheimer's disease pathogenesis. Journal of Alzheimer's Disease, 46(1), 17-34. https://doi.org/10.3233/JAD-142682

Theofilas, P., Ehrenberg, A. J., Dunlop, S., Di Lorenzo Alho, A. T., Nguy, A., Leite, R. E. P., ... Grinberg, L. T. (2017). Locus coeruleus volume and cell population changes during Alzheimer's disease progression: A stereological study in human postmortem brains with potential implication for early-stage biomarker discovery. Alzheimer's and Dementia, 
medRxiv preprint doi: https://doi.org/10.1101/2020.11.16.20232561; this version posted February $2,2021$. The copyright holder for this preprint (which was not certified by peer review) is the author/funder, who has granted medRxiv a license to display the preprint in It is made available under a CC-BY-NC-ND 4.0 International license .

LOWER LOCUS COERULEUS INTEGRITY IN ALZHEIMER'S

13(3), 236-246. https://doi.org/10.1016/j.jalz.2016.06.2362

1095

1096

1097

1098

1099

1100

1101

1102

1103

1104

1105

1106

1107

1108

1109

1110

1111

1112

1113

1114

1115

1116

Tombaugh, T. (2004). Trail Making Test A and B: Normative data stratified by age and education. Archives of Clinical Neuropsychology, 19(2), 203-214. https://doi.org/10.1016/S0887-6177(03)00039-8

Tona, K. D., Keuken, M. C., de Rover, M., Lakke, E., Forstmann, B. U., Nieuwenhuis, S., \& van Osch, M. J. P. (2017). In vivo visualization of the locus coeruleus in humans: Quantifying the test-retest reliability. Brain Structure and Function, 222(9), 4203-4217. https://doi.org/10.1007/s00429-017-1464-5

Uematsu, A., Tan, B. Z., Ycu, E. A., Cuevas, J. S., Koivumaa, J., Junyent, F., ... Johansen, J. P. (2017). Modular organization of the brainstem noradrenaline system coordinates opposing learning states. Nature Neuroscience, 20(11), 1602-1611. https://doi.org/10.1038/nn.4642

Van Cauwenberghe, C., Van Broeckhoven, C., \& Sleegers, K. (2016, May 1). The genetic landscape of Alzheimer disease: Clinical implications and perspectives. Genetics in Medicine. Nature Publishing Group. https://doi.org/10.1038/gim.2015.117

Wagatsuma, A., Okuyama, T., Sun, C., Smith, L. M., Abe, K., \& Tonegawa, S. (2018). Locus coeruleus input to hippocampal CA3 drives single-trial learning of a novel context. Proceedings of the National Academy of Sciences of the United States of America, 115(2), E310-E316. https://doi.org/10.1073/pnas.1714082115

Wang, H., Suh, J. W., Das, S. R., Pluta, J. B., Craige, C., \& Yushkevich, P. A. (2013). Multiatlas segmentation with joint label fusion. IEEE Transactions on Pattern Analysis and Machine Intelligence, 35(3), 611-623. https://doi.org/10.1109/TPAMI.2012.143

Wechsler, D. (1981). WAIS-R manual: Wechsler Adult Intelligence Scale-Revised. New York: Psychological Corporation.

Wechsler, D. (1997). WAIS-III : administration and scoring manual : Wechsler Adult Intelligence Scale (3rd ed.). [San Antonio Tex]: Psychological Corporation. 
medRxiv preprint doi: https://doi.org/10.1101/2020.11.16.20232561; this version posted February 2, 2021. The copyright holder for this preprint (which was not certified by peer review) is the author/funder, who has granted medRxiv a license to display the preprint in It is made available under a CC-BY-NC-ND 4.0 International license.

LOWER LOCUS COERULEUS INTEGRITY IN ALZHEIMER'S

1120 Weinshenker, D. (2018). Long road to ruin: Noradrenergic dysfunction in neurodegenerative disease. Trends in Neurosciences, 41(4), 211-223. https://doi.org/10.1016/j.tins.2018.01.010

1123 World Health Organization. (2004). ICD-10 : international statistical classification of diseases and related health problems : tenth revision. World Health Organization.

1125 Ye, R., Rua, C., O’Callaghan, C., Jones, P. S., Hezemans, F. H., Kaalund, S. S., ... Rowe, J. B. (2021). An in vivo probabilistic atlas of the human locus coeruleus at ultra-high field. NeuroImage, 225, 117487. https://doi.org/10.1016/j.neuroimage.2020.117487

1128 Yescas, P., Huertas-Vazquez, A., Villarreal-Molina, M. T., Rasmussen, A., Tusié-Luna, M. T., 1129 López, M., ... Alonso, M. E. (2006). Founder effect for the Ala431Glu mutation of the 1130 presenilin 1 gene causing early-onset Alzheimer's disease in Mexican families. Neurogenetics, 7(3), 195-200. https://doi.org/10.1007/s10048-006-0043-3 